\title{
Morphological, molecular and toxigenic characteristics of Namibian Pseudo- nitzschia species - including Pseudo-nitzschia bucculenta sp. nov.
}

\author{
Frederik Frøsig Gai ${ }^{\mathrm{a}}$, Cecilie Kirketerp Hedemand ${ }^{\mathrm{a}}$, Deon C. Louw ${ }^{\mathrm{b}}$, Kolette Grobler ${ }^{\mathrm{c}}$, \\ Bernd Krock $^{\mathrm{d}}$, Øjvind Moestrup ${ }^{\mathrm{e}}$, Nina Lundholm ${ }^{\mathrm{a}, *}$ \\ ${ }^{a}$ Natural History Museum of Denmark, University of Copenhagen, Sølvgade 83S, 1307, Copenhagen K, Denmark \\ ${ }^{\mathrm{b}}$ Ministry of Fisheries and Marine Resources, National Marine Information and Research Centre (NatMIRC), Swakopmund, P.O. Box 912, Namibia \\ ${ }^{c}$ Ministry of Fisheries and Marine Resources, National Marine Information and Research Centre (NatMIRC), Lüderitz, PO Box 394, Shark Island, Namibia \\ d Alfred Wegener Institute, Helmholtz Centre for Polar and Marine Research, Am Handelshafen 12, 27570, Bremerhaven, Germany \\ ${ }^{\mathrm{e}}$ Marine Biological Section, University of Copenhagen, Universitetsparken 4, 2100, Copenhagen $\emptyset$, Denmark
}

A R T I C L E I N F O

\section{Keywords:}

Pseudo-nitzschia

Namibia

Benguela

Upwelling

Domoic acid

P. bucculenta

Phylogeny

ASP toxin

\begin{abstract}
A B S T R A C T
A field study was undertaken to investigate the occurrence and toxin production of species in the diatom genus Pseudo-nitzschia in Namibian waters, in the extremely productive Benguela upwelling system. From surveys conducted on the $R / V$ Mirabilis and the $R / V$ !Anichab, 52 strains were morphologically determined to species level, supported by nuclear ITS rDNA data. Seven species were identified; $P$. australis, $P$. decipiens, $P$. dolorosa, $P$. fraudulenta, P. plurisecta, $P$. pungens var. cingulata, and the new species $P$. bucculenta F. Gai, C. K. Hedemand, N. Lundholm \& $\varnothing$. Moestrup sp. nov.

Molecular and morphological diversity of the Namibian Pseudo-nitzschia species is discussed. Most importantly, $P$. bucculenta is both morphologically and phylogenetically most similar to $P$. dolorosa differing mainly in valve width and densities of striae, poroids and band striae as well as by four hemi-compensatory base changes in the ITS2. Morphological and molecular differences among the strains of $P$. decipiens suggest a temperate and a warm water subdivision. The geographical and toxigenic characteristics of the identified Pseudonitzschia species are described and compared to previous studies. Initial tests of toxin production in all seven species revealed production of domoic acid (DA) in two species: one strain of $P$. australis $\left(0.074 \mathrm{pg} \mathrm{DA} \mathrm{cell}^{-1}\right)$ and two strains of $P$. plurisecta $\left(0.338 \mathrm{pg} \mathrm{DA} \mathrm{cell}^{-1}\right.$ and $0.385 \mathrm{pg} \mathrm{DA} \mathrm{cell}^{-1}$ ).
\end{abstract}

\section{Introduction}

\subsection{Pseudo-nitzschia, domoic acid and blooms}

Pseudo-nitzschia (Bacillariophyceae) is a globally distributed genus of bloom-forming pennate diatoms. Their abundance is significant in the world's oceans (Malviya et al., 2016) and presently the genus comprises more than 50 described species (Bates et al. in revision). Pseudo-nitzschia species form dense blooms which can have severe effects on the ecosystem (see below), especially because 26 species of Pseudo-nitzschia are known to produce the marine biotoxin, domoic acid (DA) (Lundholm, 2018). Domoic acid is a water-soluble amino acid that, when ingested, can cause the potentially fatal amnesic shellfish poisoning (ASP) in humans, with symptoms such as diarrhoea, shortterm memory loss, nausea and paralysis (Teitelbaum et al., 1990). Domoic acid caused deaths and symptoms of DA intake in humans during a bloom of Pseudo-nitzschia near Prince Edward Island, Canada
(Bates et al., 1989). This event resulted in high attention to Pseudonitzschia blooms and implementation of monitoring programs worldwide, and no fatalities have been documented since then (Trainer et al., 2012). Domoic acid is also harmful to animals in the marine food web, and fatalities have been recorded all over the world. Thus domoic acid poisoning (DAP) recently caused mass strandings of cetaceans in Tasmania, coupled to Pseudo-nitzschia blooms (Nash et al., 2017), in Alaska, seals, otters, walruses and cetaceans have stranded and been found dead with high DA concentrations in tissue or urine (Lefebvre et al., 2016), and along the US west coast mammals are regularly affected by DAP (McCabe et al., 2016). Seabirds like pelicans and Brandt's Cormorants have also died following ingestion of DA-contaminated anchovies (Fritz et al., 1992) and lower in the food web, fish are affected by DA (Busse et al., 2006).

\footnotetext{
* Corresponding author.

E-mail address: nlundholm@snm.ku.dk (N. Lundholm).
} 


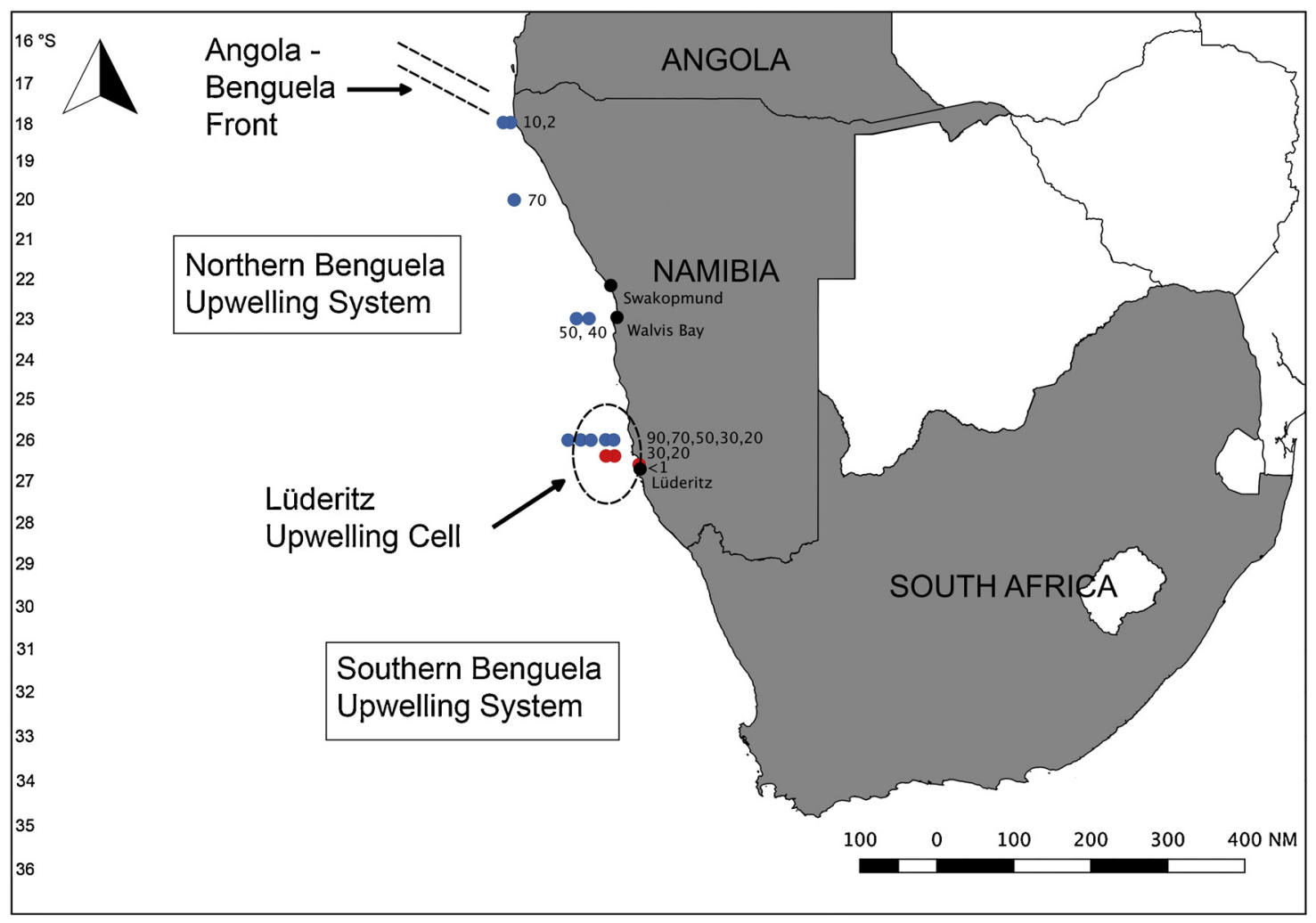

Fig. 1. Map of the Benguela current region in southwest Africa with the approximate positions of the Angola-Benguela front, the northern Benguela upwelling system, the Lüderitz upwelling cell and the southern Benguela upwelling system. Sampling stations of the $R / V$ Mirabilis survey in blue-filled circles and the $R / V$ !Anichab survey in red-filled circles.

\subsection{Namibian upwelling systems}

In Namibian waters, recurring blooms of Pseudo-nitzschia are coupled to the nBUS (Fig. 1), which is considered one of the most productive marine ecosystems in the world (Lachkar and Gruber, 2012). Upwelling in the nBUS is primarily driven by southerly or southwesterly wind forcing that drives Ekman transport, which forces surface waters to the west. This in turn causes upwelling when nutrient-rich bottom water is forced east towards the coast and upwards due to changes in coastal bathymetry. Pseudo-nitzschia spp. take advantage of the upwelling and blooms in the photic zone (Lelong et al., 2012). The nBUS is delimited in the south by the powerful Lüderitz Upwelling Cell (LUC) (Fig. 1), an area of strong winds, high offshore advection and abrupt bathymetric changes that cause turbulent mixing and upwelling. The LUC divides the nBUS from the sBUS (Hart and Currie, 1960; Rae, 2005; Hutchings et al., 2009) and it has been characterised as the most intense upwelling centre globally in terms of wind forcing (Bakun, 1996). In the north, the nBUS is defined by a strong temperature front, the Angola-Benguela Front (ABF) (Fig. 1). The surface currents of the $\mathrm{ABF}$ are highly mobile, and shifts in north/south directions occur rapidly, sometimes on a weekly basis; however, the front maintains its position between $14^{\circ} \mathrm{S}$ and $16^{\circ} \mathrm{S}$ throughout the year (Meeuwis and Lutjeharms, 1990). High temperature undercurrents bring bottom water into the nBUS below the thermocline and form a temperature front defining the nBUS in the north (Shannon et al., 1987; Mohrholz et al., 2008). Occasionally, the ABF pushes further south into the nBUS, during periods of low wind pressure, causing a local "El Niño" event the "Benguela Niño" (Shannon et al., 1986; Florenchie et al., 2003), which can cause sea surface temperature anomalies above $4{ }^{\circ} \mathrm{C}$ (Rouault et al., in press).

\subsection{Pseudo-nitzschia spp. in Namibia and southern Africa}

In the Southern Hemisphere, off the coast of South Africa, Angola and Namibia, little is known about the diversity and toxicity of Pseudonitzschia species (Trainer et al., 2012). The abundance of Pseudo-nitzschia in Namibian waters varies seasonally and annually depending on factors such as wind patterns, temperature and nutrient availability (Louw et al., 2016), however, Pseudo-nitzschia blooms often occur in Namibian waters, with cell concentrations exceeding 200,000 cells L $^{-1}$, occasionally reaching 1 million cells $\mathrm{L}^{-1}$ (Louw et al., 2017). Toxicity in shellfish has been recorded in low concentrations in this region during the Namibian mariculture monitoring program (NatMIRC, unpublished data) and DA has been found in fish (Louw et al., 2018). This may cause problems for bivalve fisheries and has most likely resulted in fatalities of local marine wildlife (Louw, unpublished). Domoic acid was, however, also found in molluscs north of this region, in Luanda, Angola, following blooms of Pseudo-nitzschia spp. containing cellular DA (CDA) up to 5 pg DA cell ${ }^{-1}$ (Blanco et al., 2010).

Species such as $P$. australis, $P$. fraudulenta and $P$. subpacifica occur in the northern Benguela upwelling system (nBUS) (Marangoni et al., 2001; Guannel et al., 2015; Louw et al., 2018). In Namibian waters, blooms are often dominated by the occasionally toxic species $P$. fraudulenta, $P$. pungens and, most importantly, by the frequently toxic $P$. australis (Louw et al., 2018), which is notorious in causing increased levels of DA in the environment and has resulted in closures of molluscan shellfish harvesting and commercial crab fisheries worldwide (Trainer et al., 2012, Table 2 therein; McCabe et al., 2016). Pseudonitzschia spp. of the seriata group (3-4 $\mu \mathrm{m}$ or more in width, (Hasle et al., 1996)) have been reported in concentrations up to 1 million cells $\mathrm{L}^{-1}$ off Terrace Bay in a remote area of the Namibian coast (Hansen et al., 2014). Further, molecular studies have suggested the presence of either $P$. cf. subpacifica or $P$. heimii, and either $P$. turgiduloides or $P$. turgidula (Guannel et al., 2015) in Namibian waters. The molecular 
studies were, however, based on ITS1 (Internal transcribed spacer 1) sequences with a divergence of up to $17 \%$ and the identifications are hence uncertain. None of the Namibian Pseudo-nitzschia species have been tested for toxicity.

In nearby African waters, Pseudo-nitzschia spp. and DA have also been found. In South Africa, in the southern Benguela upwelling system (sBUS), particulate DA reaching $0.1-3 \mu \mathrm{g} \mathrm{DA} \mathrm{L}^{-1}$ was found during a dense bloom of Pseudo-nitzschia spp. comprising what was presumably P. australis (Fawcett et al., 2007; Seeyave et al., 2009). Later, in the same region, Pseudo-nitzschia spp. cells were found containing pDA levels of 0.21 pg DA cell ${ }^{-1}$ (Hubbart et al., 2012). Presence of various Pseudo-nitzschia species along the African west coast was reviewed by Hasle (2002), who, based on earlier studies and unpublished observations, described the presence of $P$. australis, $P$. delicatissima, $P$. fraudulenta, $P$. multiseries, $P$. pseudodelicatissima, $P$. pungens and $P$. subpacifica. Only $P$. australis, $P$. fraudulenta and possibly $P$. pungens were from the southwest African waters and thus relevant for this study.

So far, species determination of Pseudo-nitzschia in Namibian waters has been restricted to either only morphological evidence (e.g. Marangoni et al., 2001; Louw et al., 2018) or to molecular sequencing (Guannel et al., 2015). In this study Pseudo-nitzschia species from Namibian waters were sampled, isolated and cultivated during a threeweek period in November-December 2016, and for the first time identifying and describing local Pseudo-nitzschia species using a combination of transmission electron microscopy (TEM) and molecular data (ITS rDNA). Potential toxin production was explored for identified Pseudo-nitzschia species during exponential and stationary growth phases.

\section{Materials and methods}

\subsection{Collection and sampling}

Net and water samples were collected during a survey on $R / V$ Mirabilis in November (8.11.2016-24.11.2016), and in Lüderitz during four shorter inshore trips on the $R / V$ !Anichab (29.11.2016-2.12.2016) and during a monthly survey on the $R / V$ !Anichab (8.12.2016) (Table 1 , Table A1 in Appendix A, Fig. 1). The samples from the $R / V$ Mirabilis survey in November 2016 were taken during transects perpendicular to the Namibian coast at latitudes $18^{\circ} \mathrm{S}, 20^{\circ} \mathrm{S}, 23^{\circ} \mathrm{S}, 26^{\circ} \mathrm{S}$ and at distances $2,5,10,20,30,40,50,60,70$ and 90 nautical miles (NM) from the coast for the $26^{\circ} \mathrm{S}$, up to $70 \mathrm{NM}$ for the $20^{\circ} \mathrm{S}$ and $23^{\circ} \mathrm{S}$, and up to $30 \mathrm{NM}$ from the coast for the $18^{\circ} \mathrm{S}$. Station names from this survey (e.g. 20070) have information of both latitude $\left(20^{\circ} \mathrm{S}\right)$ as well as distance from the coast (70 NM). Samples from the short inshore trips on the $R / V$ !Anichab were taken inside the Lüderitz Lagoon and in Shearwater Bay, both $<1 \mathrm{NM}$ off the coast. The samples from the monthly survey on the $R / V$ !Anichab were taken in the Lüderitz Lagoon, in Shearwater Bay and at distances of 1, 2, 5, 10, 20, 30 and $40 \mathrm{NM}$ perpendicular to the coast. Only sampling stations containing isolated Pseudo-nitzschia spp. are depicted on the map (Fig. 1) and in Table 1.

In order to make qualitative analyses and to establish cultures, plankton net samples were taken at all stations, using a $20 \mu \mathrm{m}$ plankton net (with a $30 \mathrm{~cm}$ diameter) drawn vertically in the upper part of the photic zone $(\sim 30 \mathrm{~m})$. From the net samples, one part was fixed in acidic Lugol's solution (3-5\% of the total sample volume) and another part was kept alive, diluted in filtered seawater and placed in a cooling box. Water samples were taken using Niskin bottles and either fixed in acidic Lugol's solution or kept alive.

\subsection{Isolation and cultivation}

At the facilities of the National Marine Information and Research Centre (NatMIRC) in Lüderitz and Swakopmund, Namibia, the live netand water samples were inspected and single cells or chains of Pseudonitzschia spp. were isolated with a dragged glass pipette using an inverted light microscope (Zeiss, Axiovert 200). The isolates were washed in drops of L1 culture medium (Guillard and Hargraves, 1993) and transferred to 96-well plates containing L1 growth medium based on local filtered sea water with a salinity of $37-38$. The isolates were kept

Table 1

Overview of isolated Pseudo-nitzschia strain ID, determined species, accession number (acc. no.), sampling station ID and sampling date. Sampling stations can be seen on Fig. 1. S.B.A = Shearwater Bay A. * = inshore sampling stations.

\begin{tabular}{|c|c|c|c|c|c|c|c|c|c|}
\hline \multicolumn{2}{|c|}{$R / V$ Mirabilis survey } & \multirow[b]{2}{*}{ Acc. no } & \multirow[b]{2}{*}{ Station ID } & \multirow[b]{2}{*}{ Date } & \multicolumn{2}{|c|}{$R / V !$ Anichab survey } & \multirow[b]{2}{*}{ Acc. no } & \multirow[b]{2}{*}{ Station ID } & \multirow[b]{2}{*}{ Date } \\
\hline ID & Species & & & & ID & Species & & & \\
\hline $\mathrm{S} 1.1$ & P. fraudulenta & & $18002^{*}$ & $21 / 11 / 16$ & L1.1 & P. bucculenta & MH376340 & S.B. $A^{*}$ & $30 / 11 / 16$ \\
\hline S1.3 & P. dolorosa & & $18002^{*}$ & $21 / 11 / 16$ & $\mathrm{~L} 1.2$ & P. plurisecta & & S.B. $A^{*}$ & $30 / 11 / 16$ \\
\hline S1.4 & P. fraudulenta & & $18002^{*}$ & $21 / 11 / 16$ & L1.3 & P. bucculenta & MH376341 & S.B. A* & $30 / 11 / 16$ \\
\hline S1.6 & P. decipiens & MH376345 & 20070 & $17 / 11 / 16$ & L1.4 & P. plurisecta & MH376351 & S.B. A* & $30 / 11 / 16$ \\
\hline S1.7 & P. decipiens & MH376346 & 20070 & $17 / 11 / 16$ & L1.5 & P. plurisecta & & S.B. A* & $30 / 11 / 16$ \\
\hline S1.9 & P. decipiens & & 20070 & $17 / 11 / 16$ & L1.13 & P. plurisecta & & S.B. A* & $30 / 11 / 16$ \\
\hline S1.12 & P. decipiens & & 20070 & $17 / 11 / 16$ & L1.16 & P. bucculenta & MH376342 & S.B. $A^{*}$ & $30 / 11 / 16$ \\
\hline $\mathrm{S} 1.22$ & P. dolorosa & & 26090 & $15 / 11 / 16$ & L1.17 & P. plurisecta & & S.B. A* & $30 / 11 / 16$ \\
\hline S1.26 & P. dolorosa & & 26090 & $15 / 11 / 16$ & L1.20 & P. plurisecta & & S.B. A* & $30 / 11 / 16$ \\
\hline S1.32 & P. dolorosa & & 26070 & $15 / 11 / 16$ & L2.6 & P. bucculenta & MH376339 & $30 \mathrm{NM}$ & $08 / 12 / 16$ \\
\hline S1.41 & P. dolorosa & & 26070 & $15 / 11 / 16$ & L2.11 & P. bucculenta & & $30 \mathrm{NM}$ & $08 / 12 / 16$ \\
\hline S1.42 & P. dolorosa & & 26070 & $15 / 11 / 16$ & L2.15 & P. bucculenta & & $30 \mathrm{NM}$ & $08 / 12 / 16$ \\
\hline S2.1 & P. fraudulenta & MH376349 & 18010 & $21 / 11 / 16$ & L3.1 & P. plurisecta & MH376352 & $20 \mathrm{NM}$ & $08 / 12 / 16$ \\
\hline $\mathrm{S} 2.2$ & P. fraudulenta & & 18010 & $21 / 11 / 16$ & L3.2 & P. pungens var. cingulata & & $20 \mathrm{NM}$ & $08 / 12 / 16$ \\
\hline S2.4 & P. fraudulenta & & 18010 & $21 / 11 / 16$ & L3.4 & P. australis & & $20 \mathrm{NM}$ & $08 / 12 / 16$ \\
\hline S2.7 & P. fraudulenta & MH376348 & 18010 & $21 / 11 / 16$ & L3.5 & P. australis & & $20 \mathrm{NM}$ & $08 / 12 / 16$ \\
\hline S2.8 & P. fraudulenta & MH376347 & 18010 & $21 / 11 / 16$ & L3.7 & P. australis & & $20 \mathrm{NM}$ & $08 / 12 / 16$ \\
\hline S2.9 & P. fraudulenta & & 18010 & $21 / 11 / 16$ & L3.8 & P. australis & & $20 \mathrm{NM}$ & $08 / 12 / 16$ \\
\hline S2.10 & P. fraudulenta & & 18010 & $21 / 11 / 16$ & L3.9 & P. plurisecta & MH376350 & $20 \mathrm{NM}$ & $08 / 12 / 16$ \\
\hline S2.11 & P. fraudulenta & & 18010 & $21 / 11 / 16$ & L3.11 & P. australis & & $20 \mathrm{NM}$ & $08 / 12 / 16$ \\
\hline S2.16 & P. dolorosa & & 23050 & $11 / 11 / 16$ & L3.13 & P. pungens var. cingulata & MH376355 & $20 \mathrm{NM}$ & $08 / 12 / 16$ \\
\hline S2.30 & P. dolorosa & MH376343 & 26020 & $11 / 11 / 16$ & L3.15 & P. australis & MH376353 & $20 \mathrm{NM}$ & $08 / 12 / 16$ \\
\hline S2.31 & P. dolorosa & & 26020 & $11 / 11 / 16$ & L3.16 & P. australis & MH376354 & $20 \mathrm{NM}$ & $08 / 12 / 16$ \\
\hline S3.1 & P. dolorosa & & 26050 & $11 / 11 / 16$ & L3.17 & P. pungens var. cingulata & & $20 \mathrm{NM}$ & $08 / 12 / 16$ \\
\hline S3.2 & P. dolorosa & MH376344 & 26050 & $11 / 11 / 16$ & L3.18 & P. australis & & $20 \mathrm{NM}$ & $08 / 12 / 16$ \\
\hline S3.13 & P. dolorosa & & 26050 & $11 / 11 / 16$ & & & & & \\
\hline S4.1 & P. dolorosa & & 26030 & $11 / 11 / 16$ & & & & & \\
\hline
\end{tabular}


at $15-20^{\circ} \mathrm{C}$ in a $12: 12$ light:dark cycle provided by $\sim 50-100 \mu \mathrm{mol}$ photons $\mathrm{m}^{-2} \mathrm{~s}^{-1}$ cool white light.

The samples were transferred in cooling boxes to the culture facilities of the Natural History Museum in Copenhagen, Denmark. Successful isolates were here transferred to $50-\mathrm{mL}$ flasks and cultivated for 14 days at $15^{\circ} \mathrm{C}$ in a $16: 8$ light:dark cycle at $\sim 30-50 \mu \mathrm{mol}$ photons $\mathrm{m}^{-2} \mathrm{~s}^{-1}$ cool white light, before harvesting for species determination based on TEM and DNA sequencing. For TEM, the cultures were fixed in $3 \%$ acidic Lugol's solution and kept dark and cool. For DNA sequencing, $1.5 \mathrm{~mL}$ dense cultures were pipetted into 1.5-mL Eppendorf tubes and frozen $\left(-20^{\circ} \mathrm{C}\right)$ until further analyses. From 155 successfully established cultures of Pseudo-nitzschia, the most different-looking strains based on light microscopic morphological characters like cell length, width and shape, chain length, cell overlap in chains, as well as strains from as diverse stations as possible were chosen for species identification (52 cultures).

\subsection{Morphological studies based on TEM}

The Pseudo-nitzschia spp. samples were cleaned of organic components using sulphuric acid, potassium permanganate and oxalic acid following Lundholm et al. (2002). The cleaned samples were mounted on carbon-coated grids by applying droplets of the sample onto the grids and letting them dry at $40^{\circ} \mathrm{C}$. The grids were inspected in TEM (JEOL 1010, Jeol, Tokyo, Japan) and digital micrographs were taken of entire valves, close-ups of cell ends and close-ups of the middle of the valves, including details of poroid organisation. For known species, ten valves were measured, and for potentially new species, 20 valves were measured.

\subsection{DNA-extraction, amplification, sequencing and secondary structure}

DNA was extracted using a modified $2 \times$ CTAB method (Lundholm et al., 2002). For PCR, the primers ITS1 and ITS4 (White et al., 1990) were used to amplify the ITS region of nuclear rDNA, using initially one denaturation step at $94{ }^{\circ} \mathrm{C}(2 \mathrm{~min})$, then 36 cycles at $94^{\circ} \mathrm{C}(30 \mathrm{~s}$. $), 50{ }^{\circ} \mathrm{C}$ (30 s.), $72{ }^{\circ} \mathrm{C}\left(45 \mathrm{~s}\right.$.) and finally $72^{\circ} \mathrm{C}$ for $10 \mathrm{~min}$. For some samples an annealing step of $52^{\circ} \mathrm{C}-56^{\circ} \mathrm{C}$ was used. Successful PCR products were purified following the QIAquick PCR purification kit protocol and sent to Macrogen Inc. for sequencing, using the PCR primers as well as sometimes ITS2 and ITS3 (White et al., 1990).

The alignment of the ITS rDNA sequences was performed using Clustal W (Thompson et al., 1994) in BIOEDIT (Hall, 1999). Pseudonitzschia spp. sequences were included from GenBank. Twenty strains from the present study were included in the alignment, which added up to 96 strains including those from GenBank (Table B1 in Appendix B). The total alignment comprised 961 base pairs. Ambiguously aligned positions were excluded from the analyses, which were based on 742 base pairs. All analyses were conducted on ITS as well as the complete ITS2 only. Three different phylogenetic analyses were conducted in PAUP (Version 4.0, Swofford, 2002): Neighbour joining (NJ) (1000 replicates) and Maximum Parsimony (MP), by heuristic searches (1000 replicates) and a branch-swapping algorithm (tree-bisection reconnection). Maximum likelihood (ML) analyses were performed using the optimal model found with a $99 \%$ level of significance using Modeltest (Posada and Crandall, 1998). Bayesian (BI) analysis was conducted using MrBayes 3.1.2 (Ronquist and Huelsenbeck, 2003) on four chains run for $1,200,000$ generations. The temperature was set to 0.2 , sample frequency was 100 and the number of burn-in generations was 3000 . For NJ, MP and ML methods, bootstrap analyses were performed to determine the robustness of the trees, while robustness in BI was determined using posterior probability. These values were conjoined in a NJ tree.

The secondary structure of ITS was predicted using the mfold server at http://unafold.rna.albany.edu/?q=mfold (Zuker, 2003). Helices were recognized by comparing the ITS regions of several Pseudo- nitzschia species following Teng et al. (2015). The helices were named according to Mai and Coleman (1997) and Amato et al. (2007). The ITS2 of $P$. bucculenta, $P$. dolorosa and $P$. simulans was compared to identify compensatory base changes (CBCs) (changes of base pairs at both sides of a helix, which thus conserve the pairing) and hemi-CBCs (HCBCs) (changes of base pairs at one side of a helix). The 'type' strains of $P$. dolorosa (strain 300) (Lundholm et al., 2006) and P. simulans (strain MC281) (Li et al., 2017) were used for the comparisons. All ITS2 sequences of $P$. bucculenta were identical. Further, the ITS2 sequences of strains of $P$. decipiens were compared for exploring differences among strains.

\subsection{Domoic acid production}

Eight strains, representing all seven species and two strains of $P$. plurisecta were selected for DA production analyses. One week prior to the experiment, exponentially growing cultures were transferred to 200-mL polystyrene flasks (Sarstedt, Germany) containing L1 medium adjusted to $\mathrm{pH} 8.0$ and adapted to $100 \mu \mathrm{mol}$ photons $\mathrm{m}^{-2} \mathrm{~s}^{-1}$ light intensity. From each exponentially growing culture, a $700-\mathrm{mL}$ batch culture containing $\sim 1500$ cells $\mathrm{mL}^{-1}$ was prepared. From this batch, triplicate Nunc bottles were filled with $200 \mathrm{~mL}$ at a concentration of $\sim 1500$ cells $\mathrm{mL}^{-1}$. From the remaining $100-\mathrm{mL}$ batch culture, $1-\mathrm{mL}$ samples were taken for RFU (Relative Fluorescence Unit) measurements and cell density. In addition, $40 \mathrm{~mL}$ samples were taken for DA analyses. The $40 \mathrm{~mL}$ were transferred to $10-\mathrm{mL}$ centrifuge glass tubes and spun down at $1200 \mathrm{G}$ for $20 \mathrm{~min}$ at $8{ }^{\circ} \mathrm{C}$. For analysis of dissolved DA (dDA), $15 \mathrm{~mL}$ of the supernatant were transferred to a Falcon tube and frozen at $-20^{\circ} \mathrm{C}$ for further analyses. For particulate DA (pDA), the remaining supernatant was removed and the pellet was resuspended in app. $500 \mu \mathrm{L}, 30$-psu sea water, transferred to a 1.5-mL Eppendorf tube, re-centrifuged for $20 \mathrm{~min}$ at $8{ }^{\circ} \mathrm{C}$, supernatant was discarded and the sample was frozen at $-20^{\circ} \mathrm{C}$. Dissolved DA was measured directly without any further treatment.

The triplicate Nunc bottles were placed on a light table in a $15{ }^{\circ} \mathrm{C}$ climate room in a 16:8 h light: dark cycle at light intensities of ca. $100 \mu \mathrm{mol}$ photons $\mathrm{m}^{-2} \mathrm{~s}^{-1}$. DA sampling was repeated when the cultures reached exponential and stationary growth phases.

Samples for RFU (all replicates) and counting (one replicate) were taken on a daily basis during the experiment to follow the growth of the cultures. From the RFU and the cell counts, standard curves were established and used to translate RFU measures into cell numbers of all replicates. DA contents of the samples were measured at the Alfred Wegener Institute, Germany using liquid chromatography coupled with tandem mass spectrometry (LC-MS/MS) as described in Krock et al. (2008).

\section{Results}

\subsection{Species identifications}

Seven different species were established in culture and identified (Table 2): P. australis (eight strains; Fig. 2), P. decipiens (four strains; Fig. 3), P. dolorosa (13 strains; Fig. 4), P. fraudulenta (ten strains; Fig. 5), $P$. plurisecta (six strains; Fig. 6), P. pungens var. cingulata (three strains; Fig. 7) and the new species $P$. bucculenta sp. nov. (six strains; Fig. 8). Species determination was based upon compliance between molecular and morphological traits, from TEM micrographs and phylogenetic analyses of ITS rDNA.

\subsection{Phylogenetic inference and secondary structure}

Overall branching pattern was similar in all the phylogenetic analyses (Fig. 9). Presentation of results will focus on clades comprising the 20 sequenced Namibian strains. Clade I (Fig. 9), a well-supported monophyletic clade with $P$. dolorosa including the Namibian $P$. dolorosa, 
Table 2

Morphometric and morphological data and species identification of Pseudo-nitzschia strains isolated during the present study.

\begin{tabular}{|c|c|c|c|c|c|c|c|c|c|c|}
\hline \multirow[t]{2}{*}{ Species } & \multirow[t]{2}{*}{$\mathrm{n}$} & \multicolumn{3}{|l|}{ Valve } & \multicolumn{2}{|l|}{ Fibulae } & \multicolumn{2}{|l|}{ Striae } & \multicolumn{2}{|l|}{ Poroids } \\
\hline & & Shape & Length $(\mu \mathrm{m})$ & Width $(\mu \mathrm{m})$ & Number/10 $\mu \mathrm{m}$ & $\begin{array}{l}\text { Central } \\
\text { nodule }\end{array}$ & Valve striae $/ 10 \mu \mathrm{m}$ & Band striae $/ 10 \mu \mathrm{m}$ & Rows/striae & Number/ $\mu \mathrm{m}$ \\
\hline P. australis & 10 & Lanceolate & $\begin{array}{l}93->118 \\
104.4 \pm 11.5\end{array}$ & $\begin{array}{l}5.1-7.9 \\
6.1 \pm 0.8\end{array}$ & $\begin{array}{l}12-17 \\
14.6 \pm 1.6\end{array}$ & NO & $\begin{array}{l}13-17 \\
14.7 \pm 1.3\end{array}$ & $\begin{array}{l}20.5-27 \\
23.3 \pm 3.4\end{array}$ & 2 & $\begin{array}{l}3.5-4.7 \\
4.2 \pm 0.4\end{array}$ \\
\hline P. bucculenta & 20 & Lanceolate & $\begin{array}{l}19-31 \\
24.9 \pm 3.6\end{array}$ & $\begin{array}{l}2.7-3.6 \\
3.0 \pm 0.3\end{array}$ & $\begin{array}{l}16-21 \\
18.4 \pm 1.2\end{array}$ & YES & $\begin{array}{l}28-35 \\
31.4 \pm 1.7\end{array}$ & $\begin{array}{l}38-39 \\
38 \pm 0.6\end{array}$ & $1-2$ & $\begin{array}{l}5-7.5 \\
6.7 \pm 0.6\end{array}$ \\
\hline P. decipiens & 10 & Lanceolate & $\begin{array}{l}18-28 \\
25.0 \pm 3.0\end{array}$ & $\begin{array}{l}1.6-2.1 \\
1.8 \pm 0.2\end{array}$ & $\begin{array}{l}17-24 \\
22.0 \pm 2.1\end{array}$ & YES & $\begin{array}{l}42-48 \\
46 \pm 2.0\end{array}$ & $\begin{array}{l}46-56 \\
51.5 \pm 4.4\end{array}$ & 2 & $\begin{array}{l}7-12 \\
9.0 \pm 2.1\end{array}$ \\
\hline P. dolorosa & 10 & Lanceolate & $\begin{array}{l}40-50 \\
46.7 \pm 2.9\end{array}$ & $\begin{array}{l}1.9-2.8 \\
2.3 \pm 0.3\end{array}$ & $\begin{array}{l}18-21 \\
20.7 \pm 1.1\end{array}$ & YES & $\begin{array}{l}32-39.3 \\
36.6 \pm 1.9\end{array}$ & $\begin{array}{l}38-47 \\
41.7 \pm 2.9\end{array}$ & $1-2$ & $\begin{array}{l}6.7-10.7 \\
8.3 \pm 1.2\end{array}$ \\
\hline P. fraudulenta & 10 & Lanceolate & $\begin{array}{l}76-90 \\
82.9 \pm 3.7\end{array}$ & $\begin{array}{l}4.3-5.1 \\
4.8 \pm 0.3\end{array}$ & $\begin{array}{l}19-24 \\
21.5 \pm 1.6\end{array}$ & YES & $\begin{array}{l}20-24 \\
22.2 \pm 1.3\end{array}$ & $\begin{array}{l}35-37 \\
35.8 \pm 1.0\end{array}$ & $2-3(4)$ & $\begin{array}{l}5-6 \\
5.7 \pm 0.4\end{array}$ \\
\hline$P$. plurisecta & 10 & Lanceolate & $\begin{array}{l}42-67 \\
53.3 \pm 6.8\end{array}$ & $\begin{array}{l}1.5-1.8 \\
1.7 \pm 0.1\end{array}$ & $\begin{array}{l}21-25 \\
23.1 \pm 1.7\end{array}$ & YES & $\begin{array}{l}37.5-42 \\
40.3 \pm 1.3\end{array}$ & $\begin{array}{l}48-51 \\
49.4 \pm 1.3\end{array}$ & 1 & $\begin{array}{l}5-7 \\
5.6 \pm 0.7\end{array}$ \\
\hline $\begin{array}{l}\text { P. pungens var. } \\
\text { cingulata }\end{array}$ & 10 & Lanceolate & $\begin{array}{l}61-85 \\
72.5 \pm 7.6\end{array}$ & $\begin{array}{l}3.06-4.4 \\
3.8 \pm 0.4\end{array}$ & $\begin{array}{l}12-16 \\
14.0 \pm 1.6\end{array}$ & NO & $\begin{array}{l}11-16 \\
12.7 \pm 1.6\end{array}$ & $\begin{array}{l}15-19 \\
17.4 \pm 1.9\end{array}$ & $2(3)$ & $\begin{array}{l}3-4 \\
3.4 \pm 0.4\end{array}$ \\
\hline
\end{tabular}

appeared as a sister clade to a highly supported monophyletic group (Clade II) (Fig. 9) comprising four Namibian strains of $P$. bucculenta sp. nov. Furthermore, $P$. simulans appeared as sister taxon to $P$. dolorosa and $P$. bucculenta. Clade III (Fig. 9) comprised two groups of $P$. decipiens, Clades IIIa and IIIb, as well as $P$. sabit and $P$. galaxiae, and appeared as sister clade to a clade comprising Clades I and II. The branching pattern within Clade III was not well supported. Namibian strains of $P$. fraudulenta (Clade IV), $P$. plurisecta (Clade V), P. pungens var. cingulata (Clade VI) and $P$. australis (Clade VII) were found clustering together with other strains of the same species.

Detailed analyses of ITS2 (Fig. 10) showed the same overall pattern as Fig. 9, with Clade I, comprising $P$. dolorosa strains, forming a sister group to Clade II, comprising $P$. bucculenta. Comparing ITS2 sequences using the secondary structure, folding of the ITS2 of $P$. bucculenta revealed the typical four-helix secondary structure (I-IV) with the additional helix IIa, similar to previous results (e.g. Amato et al., 2007, Lundholm et al., 2012, Teng et al., 2015). Secondary structure comparisons of ITS2 revealed that four hemi-CBCs (HCBC) differentiated $P$. bucculenta and P. dolorosa (Table 4). The HCBCs were found as: one in helix I, one in helix II, one in helix III and one in helix IV. The single HCBCs comprised two T-A $\leftrightarrow \mathrm{T}-\mathrm{G}$ and two G-C $\leftrightarrow \mathrm{G}-\mathrm{T}$. Comparisons with $P$. simulans revealed that six HCBCs and one $\mathrm{CBC}$ differentiate $P$. bucculenta and P. simulans (Table 4). The CBC was situated in helix IV (A-T in $P$. bucculenta $\leftrightarrow$ T-A in P. simulans), and the HCBCs were found as: one in helix I, one in helix II and four in helix III. The six of the HCBCs were four G-T $\leftrightarrow \mathrm{G}-\mathrm{C}$ and two $\mathrm{T}-\mathrm{A} \leftrightarrow \mathrm{T}-\mathrm{G}$.

In the ITS2 phylogeny, Clade III (Fig. 10), which had low support, comprised two groups of $P$. decipiens, Clade IIIa (comprising the Namibian sequences and one sequence from France) and IIIb (comprising sequences from Canary Islands, Mexico and Malaysia). Comparisons of base changes in ITS2 among strains of $P$. decipiens constituting the two clades revealed that base pairs differed between clades in two positions, one T-G $\leftrightarrow$ C-G (constituting a HCBC) located in helix II and one T $\leftrightarrow$ C (in a loop in helix IV) (Table 3). Otherwise single nucleotide polymorphisms were found among strains in loops or single-stranded DNA (Table 3).

\subsection{Species descriptions}

\subsubsection{Pseudo-nitzschia australis (Frenguelli) Hasle, 1965}

Eight $P$. australis (Fig. 2) strains were isolated from the December survey from Lüderitz at sampling station 20 NM (Fig. 1, Table 1).

\subsubsection{Morphology. The morphology of $P$. australis (Table 2) agreed}

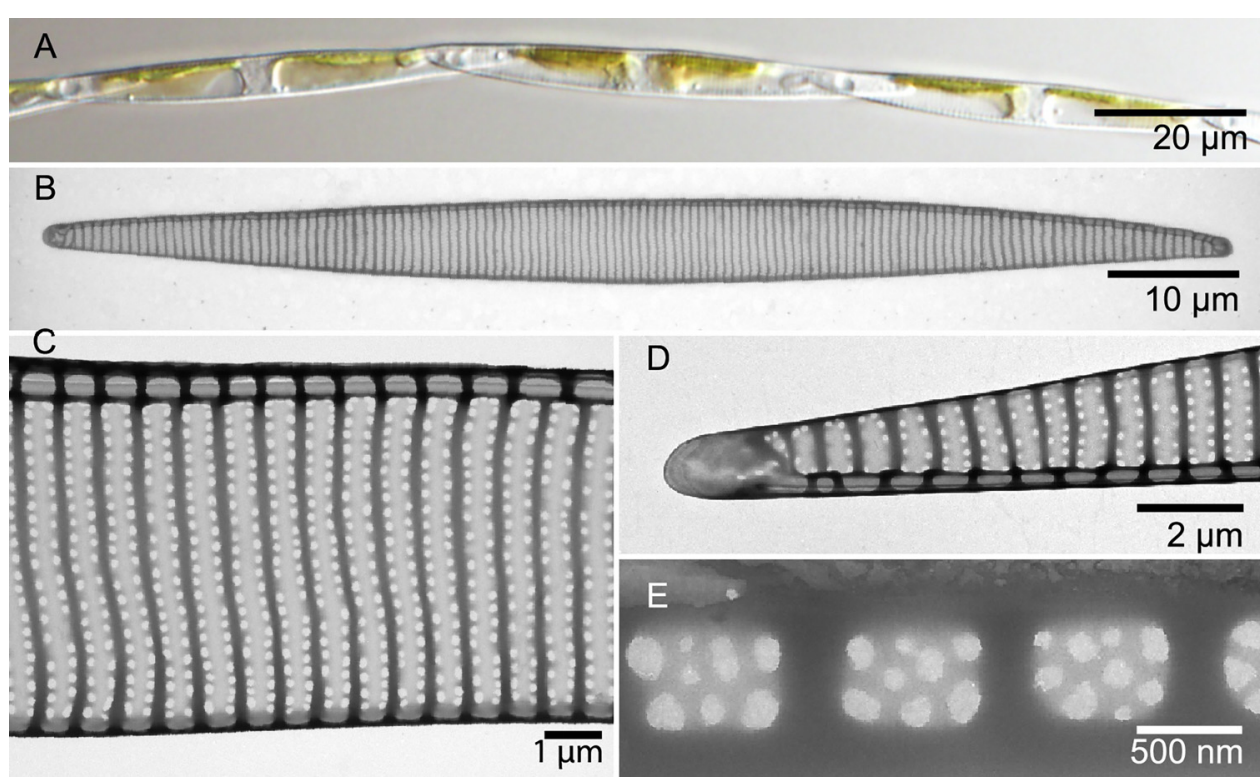

Fig. 2. Pseudo-nitzschia australis: (A): LM. Valve view of live cells in chains. (B): TEM. Valve view of entire valve showing fibulae, striae and valve symmetry. (C): TEM. Central part of valve showing absence of a central nodule as well as poroid organisation including details of fibulae and striae. (D): TEM. Apical end of valve. (E): TEM. Details of valve band. 


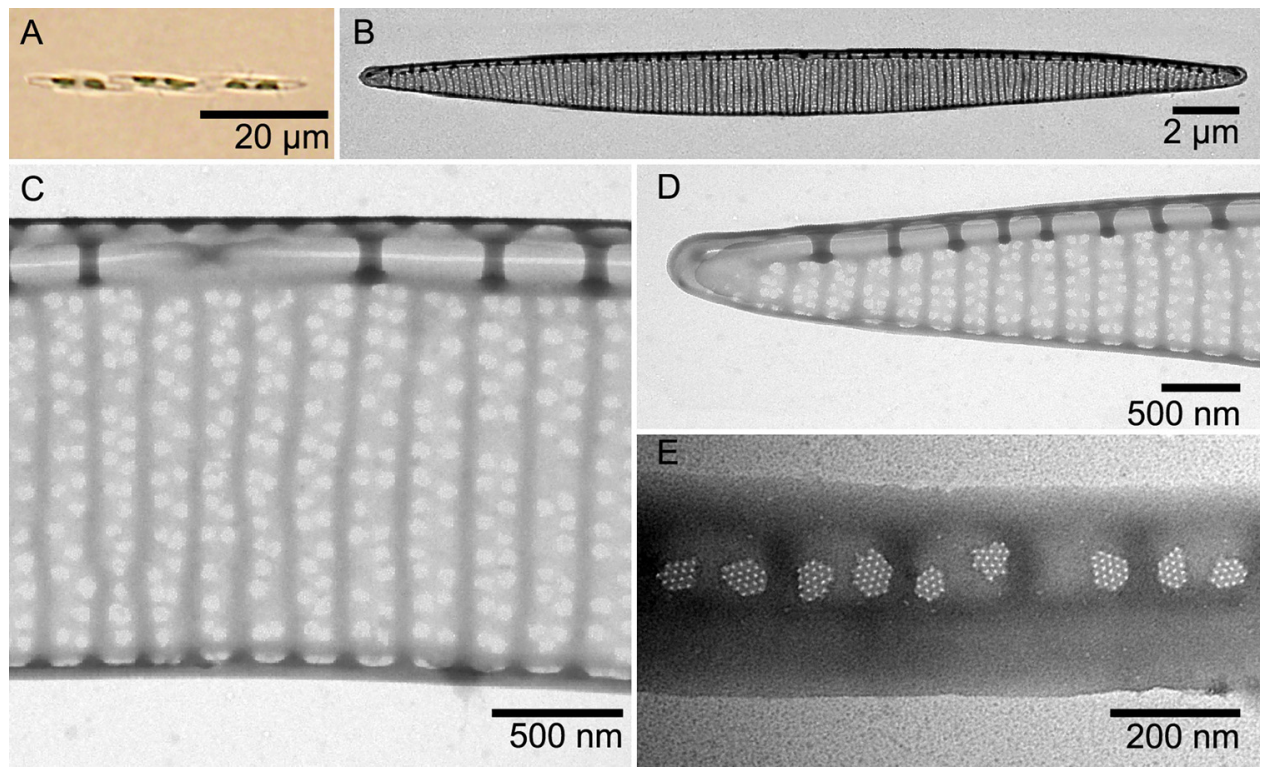

Fig. 3. Pseudo-nitzschia decipiens: (A): LM. Girdle view of live cells in chains. (B): TEM. Valve view of entire valve showing fibulae, striae and valve symmetry. (C): TEM. Central part of valve showing presence of central nodule as well as poroid organisation including details of fibulae and striae. (D): TEM. Apical end of valve. (E): TEM. Details of valve band.

with the emended type description by Hasle (1965) although specimens in the present study were narrower $(5.1-7.9 \mu \mathrm{m})$ compared to the emended description $(6.5-8 \mu \mathrm{m})$.

3.3.1.2. Molecular analyses. The two Namibian $P$. australis strains clustered in Clade VII with other $P$. australis strains (Fig. 9).

\subsubsection{Pseudo-nitzschia decipiens Lundholm and Moestrup, 2006}

Four $P$. decipiens (Fig. 3) strains were isolated from the $R / V$ Mirabilis survey at sampling station 20070 (Fig. 1, Table 1).

3.3.2.1. Morphology. Key differences in morphology of $P$. decipiens were found in this study compared to the type description (Lundholm and Moestrup, 2006) (Table 5): a lower fibula density was found in the present study $(17-24 / 10 \mu \mathrm{m})$ compared to the type $(20-26 / 10 \mu \mathrm{m})$ (Welch's $t$-test, $\mathrm{p}<0.05$ ). Poroid density was also lower in this study, $\left(7-12 \mu \mathrm{m}^{-1}\right)$ compared to the type $\left(9-13 \mu \mathrm{m}^{-1}\right)$ (Welch's $t$-test, $\mathrm{p}<0.05)$. Stria density was slightly higher in this study (42-48/ $10 \mu \mathrm{m})$ compared to Lundholm and Moestrup (2006) $(41-46 / 10 \mu \mathrm{m})$ (Welch's $t$-test, $\mathrm{p}<0.005$ ), whereas valve length had a narrower range in this study $(17.7-28 \mu \mathrm{m})$ compared to the type description $(29-64 \mu \mathrm{m})$, however not significant (Welch's $t$-test, $\mathrm{p}<0.05$ ). Compared to other P. decipiens strains (Table 5), P. decipiens from this study had overall lower but overlapping densities in fibulae, striae and poroids.

3.3.2.2. Molecular analyses. The Namibian $P$. decipiens strains clustered within the monophyletic Clade III in which other $P$. decipiens strains from GenBank were included (Fig. 10) as a moderately to highly supported sister group to $P$. sabit and $P$. galaxiae. $P$. decipiens from the present study however formed a low to highly supported monophyletic subgroup together with the PER1 strain from France in Clade IIIa (Fig. 10), as a sister group to the other low to highly supported monophyletic $P$. decipiens Clade IIIb, suggesting a subdivision of $P$. decipiens.

\subsubsection{Pseudo-nitzschia dolorosa Lundholm and Moestrup, 2006}

13 strains of $P$. dolorosa (Fig. 4) were isolated from the $R / V$ Mirabilis survey in November 2016 at various sampling stations at latitudes $18^{\circ} \mathrm{S}$ and $26^{\circ}$ S: 18002, 26030, 26050, 26070 and 26090 (Fig. 1, Table 1).

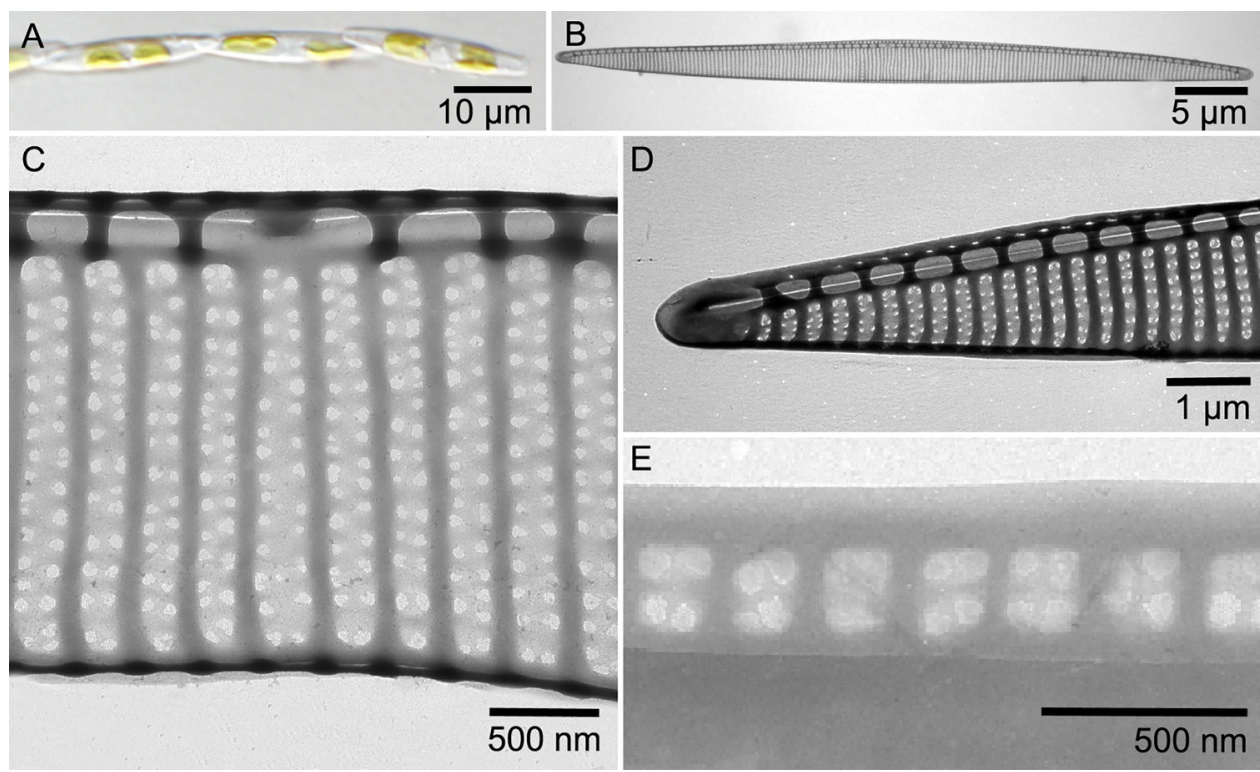

Fig. 4. Pseudo-nitzschia dolorosa: (A): LM. Valve view of live cells in chains. (B): TEM. Valve view of entire valve showing fibulae, striae and valve symmetry. (C): TEM. Central part of valve showing presence of central nodule as well as poroid organisation including details of fibulae and striae. (D): TEM. Apical end of valve. (E): TEM. Details of valvocopula. 


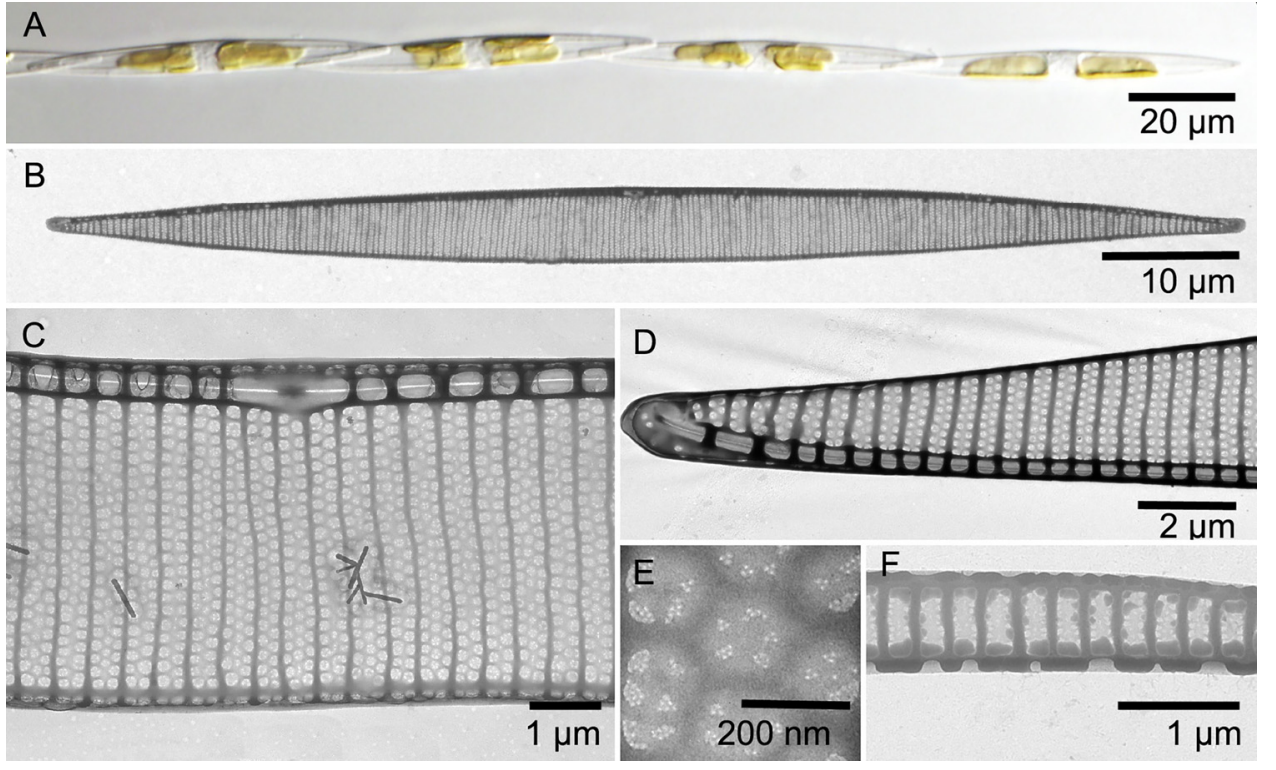

Fig. 5. Pseudo-nitzschia fraudulenta: (A): LM Valve view of live cells in chains. (B): TEM. Valve view of entire valve showing fibulae, striae and valve symmetry. (C): TEM. Central part of valve showing presence of central nodule as well as poroid organisation including details of fibulae and striae. (D): TEM. Apical end of valve. (E): TEM. Detailed poroid organisation. (F): TEM. Details of valve band.
One strain was isolated from the December survey from Lüderitz at sampling station $30 \mathrm{NM}$ (Fig. 1, Table 1).

3.3.3.1. Morphology. Compared to the type description (Lundholm and Moestrup, 2006), the morphology of the $P$. dolorosa strains (Table 2) showed the following differences: Stria density was slightly higher in this study $(32-39.3 / 10 \mu \mathrm{m})$ compared to Lundholm and Moestrup (2006) $(30-36 / 10 \mu \mathrm{m})$ (Welch's $t$-test, $\mathrm{p}<0.05)$. A wider and higher range of poroid density was found in the present study $\left(6.7-10.7 \mu \mathrm{m}^{-1}\right)$ compared to the type description $\left(5-8 \mu \mathrm{m}^{-1}\right)$. Also, a wider range was found in band striae density $(38-47 / 10 \mu \mathrm{m})$ compared to the type $(40-44 / 10 \mu \mathrm{m})$. The Namibian valve widths were smaller $(1.9-2.75 \mu \mathrm{m})$ compared to the type description $(2.5-3.0 \mu \mathrm{m})$ (Welch's $t$-test, $\mathrm{p}<0.0001)$.

3.3.3.2. Molecular analyses. The four Namibian $P$. dolorosa strains clustered within the highly supported monophyletic Clade I together with other P. dolorosa strains (Figs. 9 and 10).
3.3.4. Pseudo-nitzschia fraudulenta (Cleve) Hasle, 1993

Ten $P$. fraudulenta (Fig. 5) strains were isolated from the $R / V$ Mirabilis survey at the sampling stations 18002 and 18010 (Fig. 1, Table 1).

3.3.4.1. Morphology. The morphology of $P$. fraudulenta (Table 2) agreed with the description by Hasle (1965), except for slightly narrower valves $(4.3-5.1 \mu \mathrm{m})$ compared to the original description (4.5-6.5 $\mu \mathrm{m}$ ). Pores were divided into $2-5$ sectors (Fig. 5E).

3.3.4.2. Molecular analyses. The three Namibian $P$. fraudulenta strains clustered within the low to highly supported monophyletic Clade IV, which contained other P. fraudulenta strains (Fig. 9).

\subsubsection{Pseudo-nitzschia plurisecta Orive and Pérez-Aicua, 2013}

Six P. plurisecta (Fig. 6) strains were isolated in November from Shearwater Bay A, Lüderitz (Fig. 1, Table 1). Two strains were isolated from the December survey at the $20 \mathrm{NM}$ sampling station, Lüderitz (Fig. 1, Table 1).

3.3.5.1. Morphology. The morphology of $P$. plurisecta (Table 2) agreed

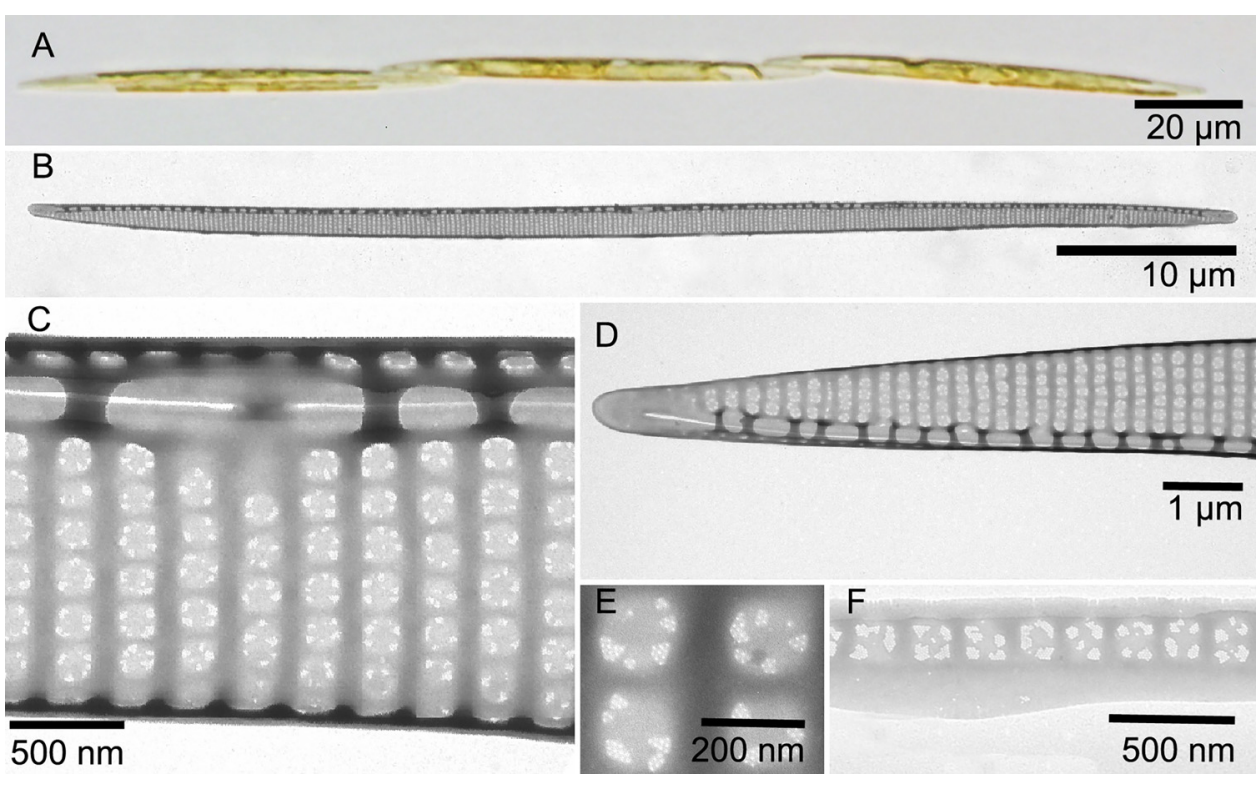

Fig. 6. Pseudo-nitzschia plurisecta: (A): LM. Valve view of live cells in chains. (B): TEM. Valve view of entire valve showing fibulae, striae and valve symmetry. (C): TEM. Central part of valve showing presence of central nodule as well as poroid organisation including details of fibulae and striae. (D): TEM. Apical end of valve. (E): TEM. Detailed poroid organisation. (F): TEM. Details of valve band. 


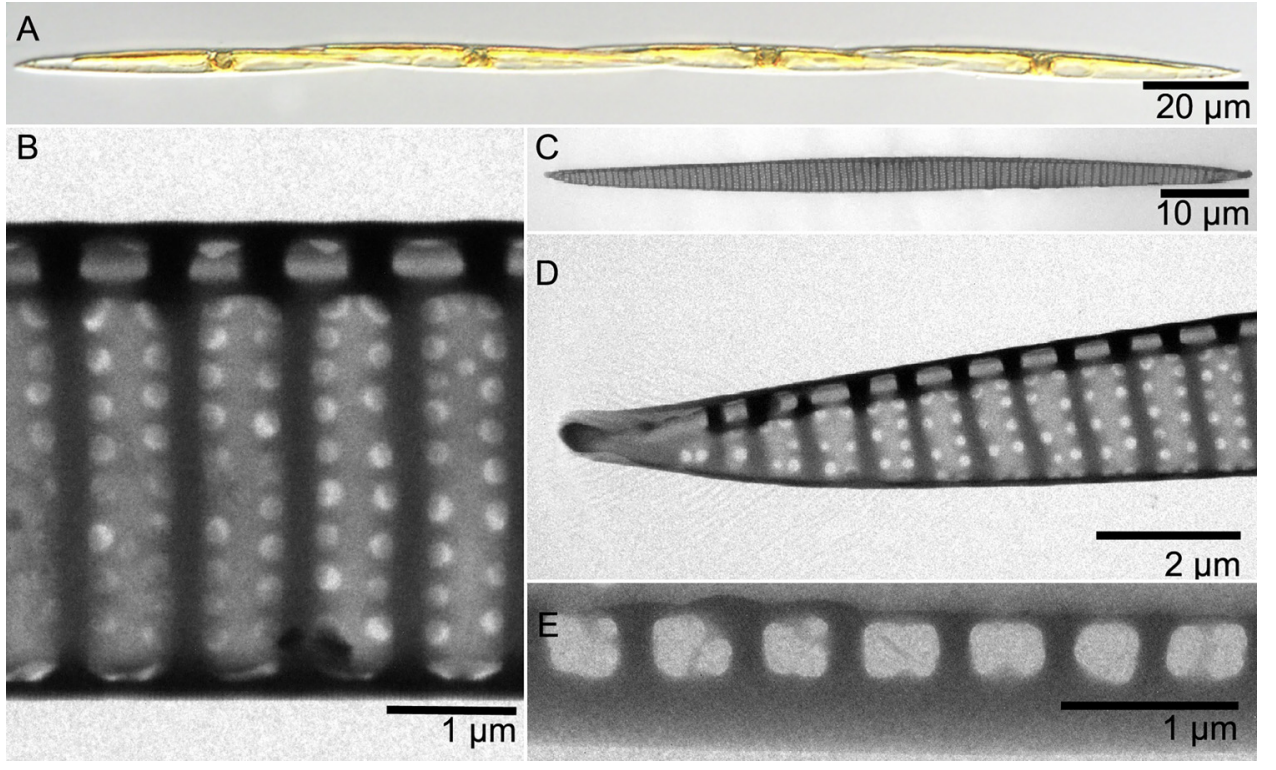

Fig. 7. Pseudo-nitzschia pungens var. cingulata: (A): LM. Valve view of live cells in chains. (B): TEM. Valve view of entire valve showing fibulae, striae and valve symmetry. (C): TEM. Central part of valve showing absence of central nodule as well as poroid organisation including details of fibulae and striae. (D): TEM. Apical end of valve. (E): TEM. Details of valve band. with the type description (Orive et al., 2013), although denser band striae were found in the present study $(48-51 / 10 \mu \mathrm{m})$ compared to the type $(45-48.5 / 10 \mu \mathrm{m})$. The poroids were divided into 3-6 sectors.

3.3.5.2. Molecular analyses. The four Namibian P. plurisecta strains clustered within the moderate to highly supported monophyletic Clade V, which contained other P. plurisecta strains (Fig. 9).

\subsubsection{Pseudo-nitzschia pungens var. cingulata Villac, 1998}

Three strains of $P$. pungens var. cingulata (Fig. 7) were isolated in November from Shearwater Bay A, Lüderitz (Fig. 1, Table 1).

3.3.6.1. Morphology. The morphology of $P$. pungens var. cingulata agreed with the emended description by Churro et al. (2009), although in the Namibian specimens, fibula and stria densities were slightly higher (fibulae: $12-16 / 10 \mu \mathrm{m}$, striae: $11-16 / 10 \mu \mathrm{m}$ ) compared to the emended description (fibulae: $10-13 / 10 \mu \mathrm{m}$, striae: $11-15 / 10 \mu \mathrm{m}$ (Churro et al., 2009)).

3.3.6.2. Molecular analyses. The Namibian P. pungens var. cingulata strain clustered within the low to moderately supported monophyletic Clade VI, which contained other $P$. pungens var. cingulata strains (Fig. 9).

\subsubsection{Pseudo-nitzschia bucculenta F. Gai, C. K. Hedemand, N. Lundholm} and $\emptyset$. Moestrup, sp. nov.

The cells formed short, stepped chains of up to 12 cells in the present study. The valves were lanceolate and more or less asymmetrical in valve view (Fig. 8A) and rectangular to lanceolate in girdle view (Fig. 8B), with valves tapering from the centre towards the isopolar apices (Fig. 8E and F). Valve width was 2.7-3.6 $\mu \mathrm{m}$ (Fig. 8C and D) and valve length $19.2-30.8 \mu \mathrm{m}$. Fibula density was $16-21 / 10 \mu \mathrm{m}$, and a central nodule was present in the interspace between the two central fibulae (Fig. 8C and D). Stria density was $28-35 / 10 \mu \mathrm{m}$. Most striae were biseriate except in the centre of the valve, where striae were often uniseriate, or the two rows merged into one row (Fig. 8C and D). The poroids were often arranged in pairs in the biseriate striae, and poroid density varied from 5.5 to $7.5 \mu^{-1}$. In the valvocopulae, the density of band striae was $38-39 / 10 \mu \mathrm{m}$. The bands consisted of a valvocopula containing four poroids in each stria (Fig. 8I), and attached on the valvocopula were two cingular bands, one perforated with one or two longitudinal rows of poroids, the other unperforated (Fig. 8J).
3.3.7.1. Diagnosis. Cells in stepped chains. Valves lanceolate and asymmetrical in valve view, more or less rectangular in girdle view, isopolar valve apices. Valve width $2.7-3.6 \mu \mathrm{m}$, valve length 19.2$30.8 \mu \mathrm{m}$. Fibula density $16-21 / 10 \mu \mathrm{m}$, and a central nodule present. Stria density $28-35 / 10 \mu \mathrm{m}$. Most striae were biseriate, occasionally uniseriate. Poroids typically arranged in pairs in the biseriate rows, and poroid density being 5.5 to $7.5 \mu \mathrm{m}^{-1}$. Density of valvocopula striae $38-39 / 10 \mu \mathrm{m}$. Valvocopula contained four poroids in each stria (Fig. 8I). Two cingular bands were present: one perforated with one or two longitudinal rows of poroids, the other unperforated.

3.3.7.2. Holotype. Fixed material of strain L1.3 deposited at the National History Museum of Copenhagen, Denmark, registered as CA-92081.

3.3.7.3. Isotype. Fixed material of L1.16 deposited at the National History Museum of Copenhagen, Denmark, registered as C-A-92082.

3.3.7.4. Type locality. Lüderitz Lagoon, Namibia.

The type $P$. bucculenta strains were isolated on the $R / V !$ Anichab survey from the Shearwater Bay A station (30.11.16) (Fig. 1, Table 1).

3.3.7.5. Etymology. (Latin) bucculenta, chubby, because of its relatively wide valve width, which makes the cells appear somewhat chubby.

3.3.7.6. Phylogeny. The four Namibian strains of $P$. bucculenta formed a monophyletic sister group to $P$. dolorosa. The grouping was highly supported in all phylogenetic analyses (Fig. 10).

3.3.7.7. Molecular signature. Synapomorphy in helix II of ITS2 of the nuclear rDNA: 5'-

GGCTCTGACCGTAACTAGTTTATGGTCTCTGCT-3' (33 bp). This sequence includes a HCBC and two insertions/deletions differentiating it from $P$. dolorosa, and one HCBC and four SNP (single nucleotide polymorphism) that differentiates it from $P$. simulans. A test for the uniqueness of the diagnostic signature of $P$. bucculenta was confirmatory; no similar sequences were found.

\subsection{Domoic acid production in Namibian Pseudo-nitzschia species}

Two (P. australis and P. plurisecta) out of seven Namibian Pseudonitzschia species were found to produce DA under the experimental 

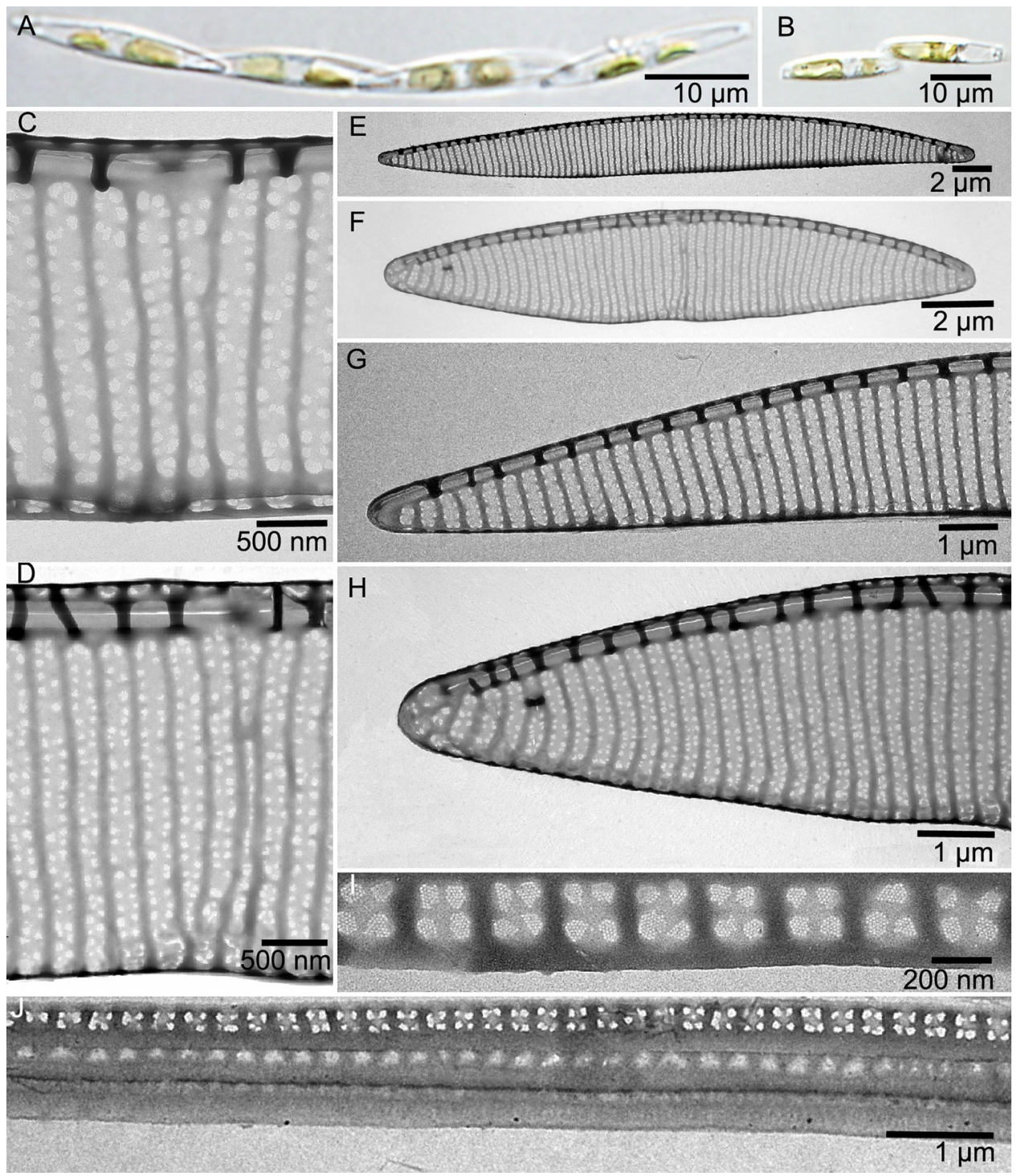

Fig. 8. Pseudo-nitzschia bucculenta sp. nov: (A): LM. Valve view of live cells in chains. (B): LM. Girdle view of live cells in chains. (C-D): TEM. Central part of valves showing presence of central nodule as well as poroid organisation including details of fibulae and striae. (E-F): TEM. Girdle view of entire valves showing fibulae, striae and valve symmetry. (G-H): TEM. Apical ends of valves. (I): TEM. Details of valvocopula. (J): TEM. Perforated valvocopula, followed by two cingular bands, one perforated and one unperforated.

conditions used (Table 6) when testing both exponential and stationary growth phases. The remaining species ( $P$. fraudulenta, $P$. decipiens, $P$. dolorosa, $P$. bucculenta, $P$. pungens var. cingulata) were not toxic, or the DA content was below the detection limit (Table 6). The toxic strains included one strain of $P$. australis and two strains of $P$. plurisecta. Initially, all toxic strains showed the highest values of pDA content: 0.074 pg DA cell ${ }^{-1}$ in $P$. australis and 0.338 pg DA cell $^{-1}$ and $0.385 \mathrm{pg}$ DA cell ${ }^{-1}$ in $P$. plurisecta. During exponential growth phases, pDA in all strains decreased significantly, but towards the end of the stationary phase, a slight increase was found in all strains. Dissolved DA was very low in all the toxic strains (Table 6) and the total DA (tDA) was therefore not much different from pDA. In all strains, at all phases, pDA and tDA were statistically higher than $\mathrm{dDA}$ (t-test, $\alpha=0.05, \mathrm{p}$ ), whereas no significant differences were found between pDA and tDA (ttest, $\alpha=0.05, \mathrm{p}<0.001$ ). The instrumental limit of detection (LOD)

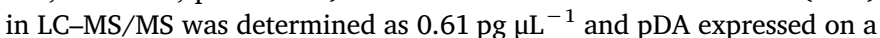
cellular basis varied between $0.1 \mathrm{fg} \mathrm{DA} \mathrm{cell}^{-1}$ and $1 \mathrm{fg} \mathrm{DA} \mathrm{cell}{ }^{-1}$ depending on analysed biomass.

\section{Discussion}

\subsection{Species phylogeny, morphology}

Seven Pseudo-nitzschia species, $P$. australis, $P$. decipiens, $P$. dolorosa, $P$. fraudulenta, $P$. plurisecta, $P$. pungens var. cingulata, and $P$. bucculenta sp. nov. were identified based on morphological and molecular data, and production of DA found in two of these, P. plurisecta and $P$. australis. The seven Pseudo-nitzschia species found represent a part of the diversity present in Namibian inshore and offshore waters (Table 1), as well as in the three ecologically important upwelling systems in Namibian waters, which are the nBUS covering the entire Namibian coast, the $\mathrm{ABF}$ in the north (which falls within the nBUS) and the LUC in the south (Fig. 1). Out of the seven species, earlier studies based on TEM (Louw et al., 2018) have reported two to possibly six, as discussed below. The species descriptions in Louw et al. (2018) were based on samplings from surveys in August 2004, collected during a toxic bloom event with reports of dead fish and seals as well as sightings of irregular seabird behaviour (Louw et al., 2018) and from frequent samplings during 2004-2011 along a $23^{\circ} \mathrm{S}$ transect line starting inshore close to 
MP/NJ/ML/BI

Bootstrap / Posterior probability

- : $<50 /<0.5$

$\Delta: 50-70 / 0.5-0.7$

口: : 70-90/ 0.7-0.9

०: $90-100 / 0.9-1.0$

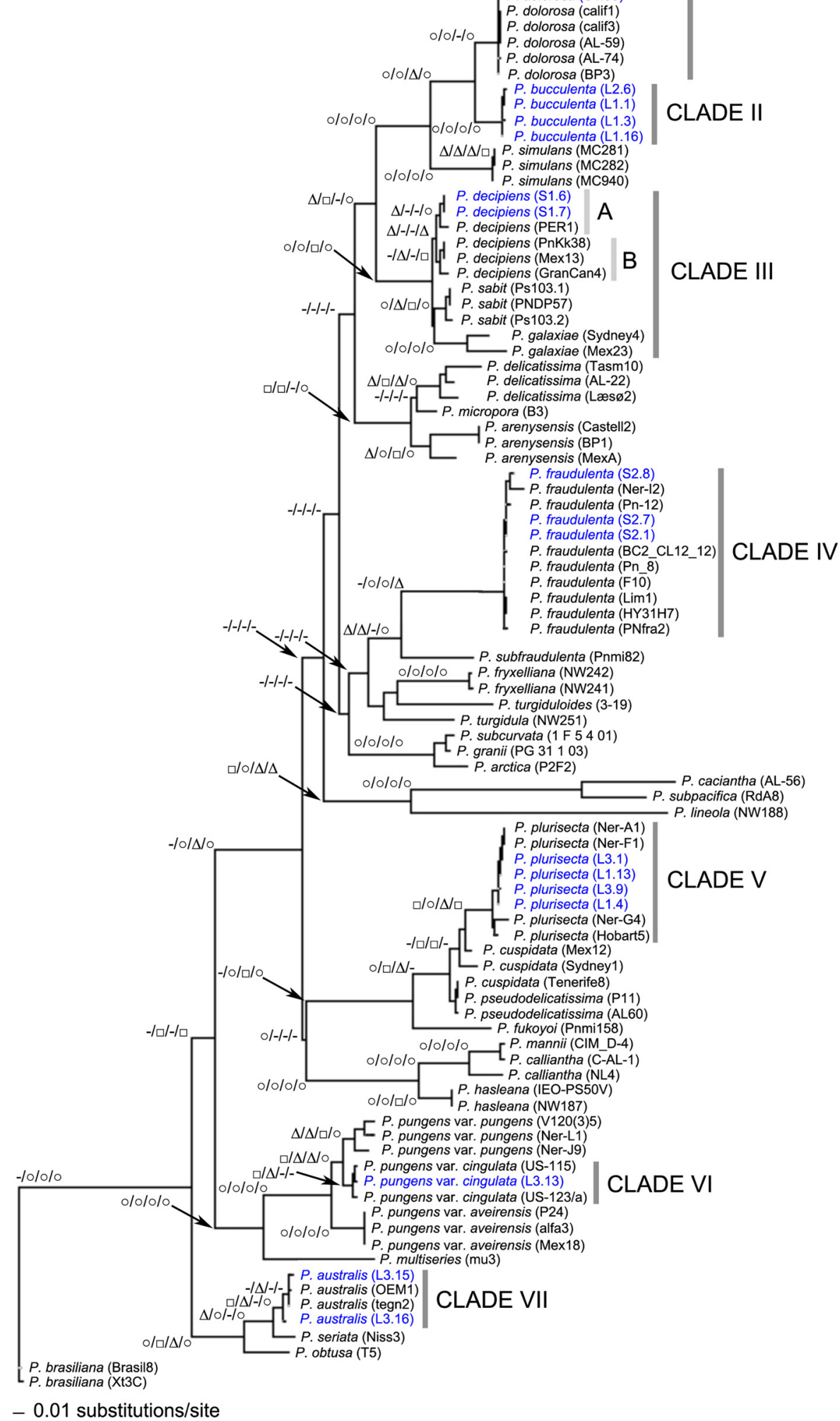

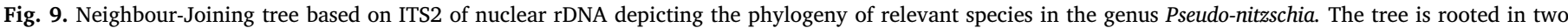

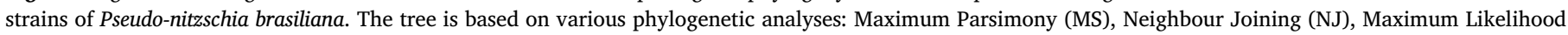

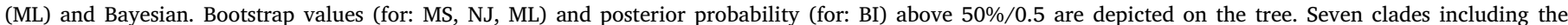
Namibian strains are labelled Clade I - VII. 


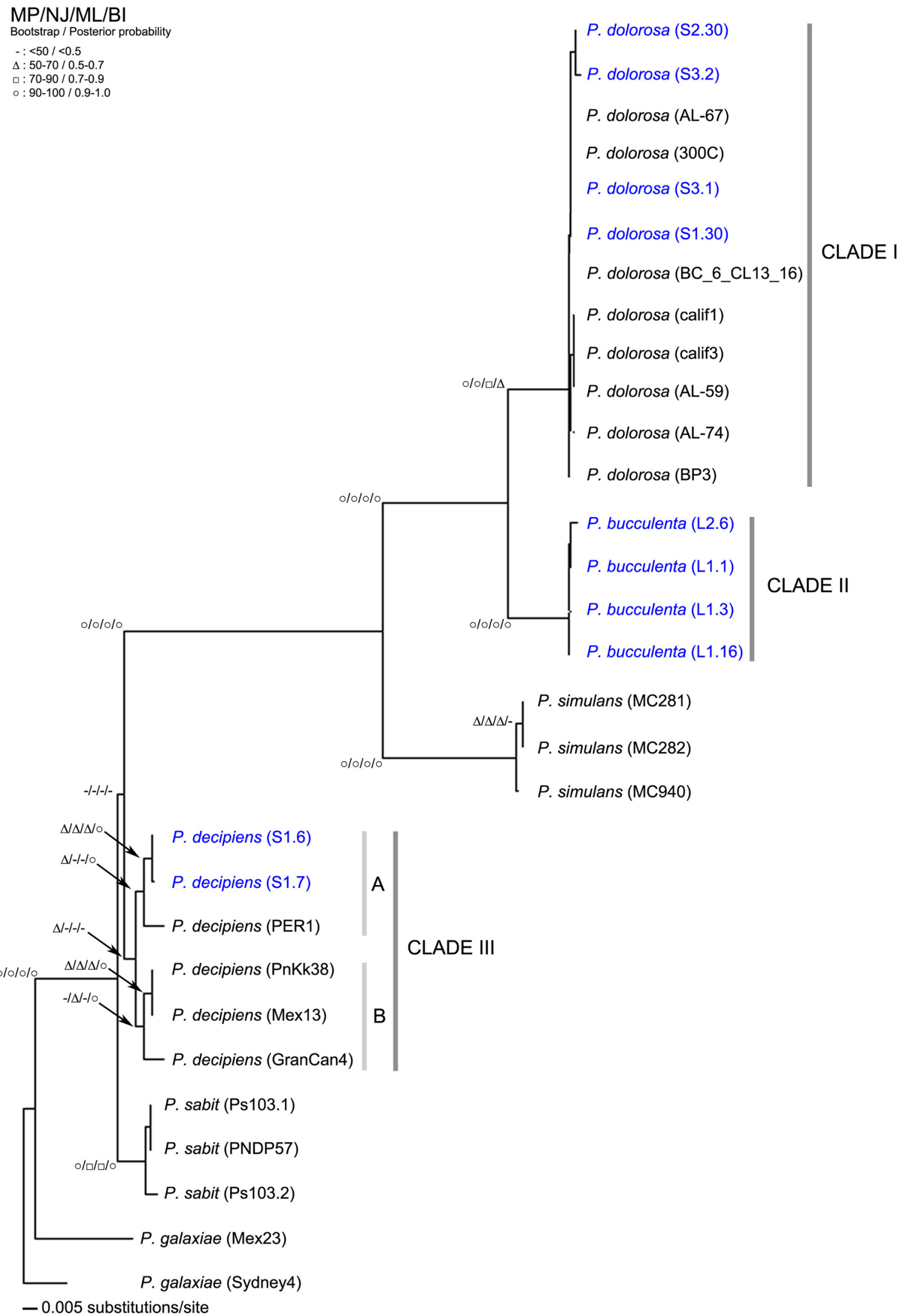

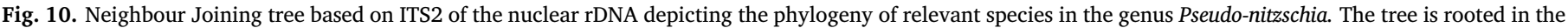

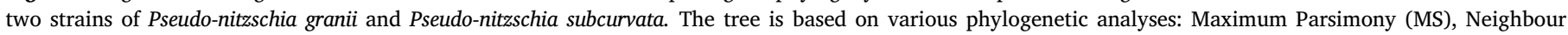

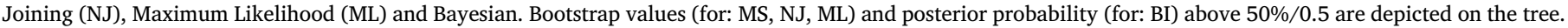
Four clades including the Namibian taxa are labelled Clade I-III, including Clades IIIa and IIIb. 
Table 3

Mismatches in ITS2 rDNA base pairs comparing $P$. decipiens from Namibia, strains in Clades IIIa and IIIb and $P$. decipiens type strain Mex13. Base pair position differing between the temperate and the tropical strains is indicated in grey, a HCBC in dark grey. Sequences from Namibia were identical except for ambiguous bases.

\begin{tabular}{llllllllll}
\hline Type of mismatch & HC & HC & HC & HC & HC & HC & HC & SNP & HCBC/CBC \\
& BC & BC & BC & BC & BC & BC & BC & & \\
\hline Position & 31 & 57 & 69 & 173 & 221 & 224 & 225 & 228 & $253-261$ \\
Helix & I & II & II & III & III & III & III & III & IV \\
$\begin{array}{llll}\text { P. bucculenta } \\
\text { P. dolorosa }\end{array}$ & A & G & T & T & T & C & C & T & A-T \\
P. simulans & G & G & C & C & T & C & C & A & G-T \\
& G & A & T & C & C & T & T & T & T-A \\
\hline
\end{tabular}

Table 4

Mismatches in ITS2 rDNA base pairs, excluding positions in loops or single strand regions, comparing $P$. bucculenta (strain No 6) with $P$. dolorosa (type strain 300) and $P$. simulans (type strain MC281). Positions are given as positions in ITS2 sequence of $P$. simulans, and position in helices are indicated. HemiCBCs and CBCs are indicated with light grey and dark grey, respectively.

\begin{tabular}{|c|c|c|c|c|c|c|c|c|}
\hline Position & 60 & 85 & 116 & 137 & 139 & 181 & 186 & 237 \\
\hline $\begin{array}{l}\text { P. decipiens, } \\
\text { Namibian strains } \\
\text { only }\end{array}$ & $C$ & $C$ & $C$ & $C$ & A & $\mathrm{T}$ & $\mathrm{T}$ & T \\
\hline $\begin{array}{l}\text { P. decipiens } \\
\text { Clade Illa }\end{array}$ & C & $\mathrm{C} / \mathrm{T}$ & $\mathrm{C} / \mathrm{T}$ & C & $A / T$ & $\mathrm{~T}$ & $\mathrm{~T}$ & T \\
\hline $\begin{array}{l}\text { P. decipiens } \\
\text { type strain } \\
\text { Mex13 }\end{array}$ & T & C & C & C & T & A & $\mathrm{T}$ & C \\
\hline $\begin{array}{l}\text { P. decipiens } \\
\text { Clade IIIb }\end{array}$ & $\mathrm{T}$ & C & C & $C / T$ & T & $A / T$ & $\mathrm{C} / \mathrm{T}$ & C \\
\hline
\end{tabular}

Walvis Bay and ending 70 NM off the coast (Louw et al., 2016). Comparisons between these morphological and morphometric descriptions of Pseudo-nitzschia and results from the present study confirmed the presence of $P$. australis, $P$. fraudulenta, $P$. pungens var. cingulata and $P$. decipiens, with $P$. australis as a dominant species.

In Namibian waters, Marangoni (NatMIRC unpublished data) found a Pseudo-nitzschia species believed to be $P$. cf. delicatissima or " $P$. occulta" in the 2004 findings (Louw et al., unpublished). The morphometrics of this 2004 species match that of $P$. decipiens from the present study, although stria density is higher in the present study and fibula density slightly lower (Table 5). The morphometrics of the 2004 species also match the morphometrics of the type description of $P$. decipiens (Lundholm and Moestrup, 2006), except for a lower stria density and a lower but overlapping range in fibula density, but with a similar poroid density, as opposed to the Namibian $P$. decipiens in the present study (Table 5). It is hence possible that the $P$. cf. delicatissima or " $P$. occulta" in the 2004 findings represent $P$. decipiens. The distribution of $P$. decipiens (Fig. 3) in the present study was limited to offshore waters at $20^{\circ} \mathrm{S}$ (Fig. 1, Table 1), whereas the distribution of the $P$. cf. decipiens found by Marangoni (NatMIRC unpublished data) was only mentioned as
"Namibian waters".

A phylogenetic division of the $P$. decipiens strains into two groups was found (Figs. 9 and 10) and supported by a single HCBC as well as a base pair difference in a loop region of ITS2. This division was moderately supported by morphological differences, as $P$. decipiens from the present study has fewer fibulae $/ 10 \mu \mathrm{m}$, band striae $/ 10 \mu \mathrm{m}$, and poroids $\mu \mathrm{m}^{-1}$ compared to Clade IIIb morphologies (Table 5). As the morphologies of the earlier findings of $P$. decipiens in Namibian waters (see above) match the type description (representing Clade IIIb) to some extent (Table 5), the morphology does not convincingly distinguish between the two clades. Looking into the geographical origins of the strains of $P$. decipiens reveals that the Namibian strains group in Clade IIIa with strain PER1 from France (Fig. 10), whereas the other Clade IIIb (Fig. 10) comprises three strains from warmer regions: Malaysia, Gran Canaria and the Mexican Gulf (Table 5). Molecular diversity within a Pseudo-nitzschia species due to differences in geographical origins has been shown in Lim et al. (2014), who reported that the gene flow in $P$. pungens var. aveirensis between temperate and tropical waters was limited, subsequently resulting in a phylogenetic sub-division of $P$. pungens var. aveirensis. Similarly, a subdivision in a European and a Southeast Asian clade was found in P. brasiliana (Wang et al., 2012). The molecular groupings of $P$. decipiens may therefore derive from differences in origin, e.g. temperate versus warmer regions. The differences noted may eventually result in $P$. decipiens being divided into two geographically separated varieties. Detailed analyses of the molecular and morphological diversity of more strains from geographically widespread localities will reveal whether $P$. decipiens should be subdivided into varieties.

\subsection{Geographical distribution of Pseudo-nitzschia species in Namibia}

Pseudo-nitzschia australis (Fig. 2) from this study was isolated from inshore regions $\sim 26^{\circ} 38$ 's (Table 1 ), and thus expanded further south. In 2004 it was found at sampling stations from $24^{\circ} \mathrm{S}$ to $18^{\circ} \mathrm{S}$ in high abundances, and $P$. australis dominated the $23^{\circ} \mathrm{S}$ transect in 2005, 2007 and 2008 (Louw et al., 2018).

Results from the present study also confirm a more southerly distribution of $P$. pungens var. cingulata (Fig. 7), i.e. inshore at $\sim 26^{\circ} 38^{\prime} \mathrm{S}$ (Table 1), previously it was found along the $18^{\circ} \mathrm{S}$ to $\sim 24^{\circ} \mathrm{S}$ transects during 2004, and during 2005-2008 it was present in high concentrations along the $23^{\circ} \mathrm{S}$ transect (Louw et al., 2018).

The distribution of $P$. fraudulenta (Fig. 5) in the present study was limited to the northern region of Namibian waters, as it was found exclusively at $18^{\circ} \mathrm{S}$ in both inshore and offshore stations (Table 1). Previously it was found at $20^{\circ} \mathrm{S}$ and $23^{\circ} \mathrm{S}$ in high concentrations in 2005 and 2011 (Louw et al., 2018), hence this expands the known distribution area from $18^{\circ} \mathrm{S}$ to $23^{\circ} \mathrm{S}$.

Pseudo-nitzschia plurisecta (Fig. 6) was found in the southern part of Namibia at $26^{\circ} \mathrm{S}, 20 \mathrm{NM}$ off the coast (Table 1 ) in proximity of the LUC (Fig. 1). The presence of $P$. plurisecta has never previously been reported

Table 5

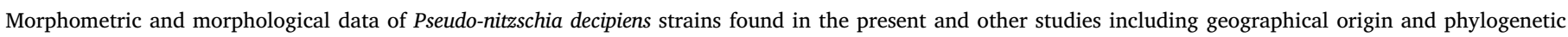
clade (Clade IIIa/Clade IIIb) based on phylogenetic analyses from the present study (Figs. 9 and 10). “-“=not described.

\begin{tabular}{|c|c|c|c|c|c|c|c|c|}
\hline Species (Strain name) & Valve & & Fibulae & Striae & & Poroids & Geo. origin & Clade \\
\hline Length $(\mu \mathrm{m})$ & Width $(\mu \mathrm{m})$ & Number $/ 10 \mu \mathrm{m}$ & Valve striae $/ 10 \mu \mathrm{m}$ & Band striae $/ 10 \mu \mathrm{m}$ & Number $/ \mu \mathrm{m}$ & & & \\
\hline \multirow[t]{2}{*}{ P. decipiens (this study) } & $17.7-28$ & $1.6-2.1$ & $17-24$ & $42-48$ & $46-56$ & $7-12$ & Namibia & $3 \mathrm{~A}$ \\
\hline & $25.0 \pm 3.0$ & $1.8 \pm 0.2$ & $22.0 \pm 2.1$ & $46 \pm 2.0$ & $51.5 \pm 4.4$ & $9.0 \pm 2.1$ & & \\
\hline P. decipiens ("P. occulta") & $30-35$ & $1.5-1.8$ & $19-21$ & $36-42$ & - & $9-13$ & Namibia & - \\
\hline P. decipiens PER1 & - & - & - & - & - & - & France & $3 \mathrm{~A}$ \\
\hline \multirow[t]{2}{*}{ P. decipiens (Type descr.) } & $29-64$ & $1.4-2.4$ & $20-26$ & $41-46$ & $48-55$ & $9-13$ & Mexico & - \\
\hline & & $1.9 \pm 0.3$ & $24.0 \pm 1.4$ & $43.2 \pm 1.2$ & $51.8 \pm 1.7$ & $11.4 \pm 1.2$ & & \\
\hline P. decipiens Mex 13 (Holotype) & 54 & $1.4-1.8$ & $22-26$ & $42-45$ & $48-53$ & $9-12$ & Mexico & 3B \\
\hline P. decipiens GranCan 4 & $29-31$ & $2.0-2.4$ & $20-25$ & $41-46$ & $48-55$ & $9-12$ & Gran Canaria & 3B \\
\hline P. decipiens PnKk38 & $41.8-49.1$ & $1.7-2.0$ & $22-26$ & $43-47$ & - & $8-13$ & Malaysia & $3 \mathrm{~B}$ \\
\hline
\end{tabular}


Table 6

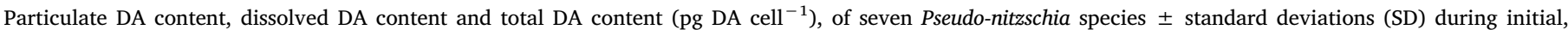
exponential and stationary phases. nd $=$ not detected.

\begin{tabular}{|c|c|c|c|c|c|c|c|c|c|c|}
\hline \multirow[t]{3}{*}{ Species } & \multirow[t]{3}{*}{ ID } & \multirow{2}{*}{\multicolumn{3}{|c|}{$\frac{\text { Initial DA content }}{\left(\text { pg cell }^{-1}\right)}$}} & \multicolumn{3}{|c|}{ Exp. phase DA content } & \multicolumn{3}{|c|}{ Stat. phase DA content } \\
\hline & & & & & \multicolumn{3}{|l|}{$\left(\right.$ pg cell $\left.{ }^{-1}\right)$} & \multicolumn{3}{|l|}{$\left(\right.$ pg cell $\left.^{-1}\right)$} \\
\hline & & $\mathrm{CDA}$ & DDA & TDA & CDA & DDA & TDA & $\mathrm{CDA}$ & DDA & TDA \\
\hline P. australis & L3.11 & 0.074 & nd & 0.074 & $0.061( \pm 0.020)$ & nd & $0.061( \pm 0.020)$ & $0.067( \pm 0.022)$ & $0.007( \pm 0.001)$ & $0.074( \pm 0.021)$ \\
\hline P. fraudulenta & $\mathrm{S} 2.1$ & nd & nd & nd & nd & nd & nd & nd & nd & nd \\
\hline P. decipiens & S1.6 & nd & nd & nd & nd & nd & nd & nd & nd & nd \\
\hline P. dolorosa & S3.1 & nd & nd & nd & nd & nd & nd & nd & nd & nd \\
\hline P. bucculenta & L1.3 & nd & nd & nd & nd & nd & nd & nd & nd & nd \\
\hline P. plurisecta & L1.13 & 0.338 & nd & 0.338 & $0.194( \pm 0.029)$ & $0.004( \pm 0.001)$ & $0.198( \pm 0.029)$ & $0.209( \pm 0.029)$ & $0.018( \pm 0.004)$ & $0.227( \pm 0.031)$ \\
\hline P. plurisecta & L3.9 & 0.385 & nd & 0.385 & $0.252( \pm 0.020)$ & $0.000( \pm 0.000)$ & $0.252( \pm 0.019)$ & $0.287( \pm 0.074)$ & $0.007( \pm 0.006)$ & $0.294( \pm 0.081)$ \\
\hline$P$. pungens var. cingulata & S3.13 & nd & nd & nd & nd & nd & nd & nd & nd & nd \\
\hline
\end{tabular}

in Namibian waters, in fact not from any coastal waters off the African continent (Bates et al. in revision). The described distribution is otherwise restricted to Australia (Tasmania), the Gulf of Maine, Malaysia and Spain (Atlantic) (Bates et al. in revision).

The distribution of $P$. dolorosa, which has not previously been reported from Namibian waters, was found to cover the entire Namibian coast, both inshore and offshore at $18^{\circ} \mathrm{S}, 23^{\circ} \mathrm{S}$ and $26^{\circ} \mathrm{S}$. Similarly, the geographical distribution of $P$. decipiens has not previously been reported in Namibian waters. This study showed $P$. decipiens to be present only at the offshore northern parts of the Namibian coast at $20^{\circ} \mathrm{S}$ (Table 1).

\subsection{Pseudo-nitzschia bucculenta sp. nov.}

The distribution of P. bucculenta (Fig. 8) was restricted to the southern parts of the Namibian waters in proximity of the LUC (Fig. 1), as it was found exclusively at $26^{\circ} \mathrm{S}$, inshore as well as offshore (Table 1). Louw et al. (2018), however, described an unidentified Pseudo-nitzschia species, $P$. cf. dolorosa, in offshore stations at $23^{\circ}$ S from 2006 and 2007. The description of $P$. cf. dolorosa in Louw et al. (2018) had a wider valve width $(2.9-3.5 \mu \mathrm{m})$ than the type description of $P$. dolorosa $(2.5-3.0 \mu \mathrm{m})$ (Lundholm et al., 2006), but resembles $P$. bucculenta $(2.7-3.6 \mu \mathrm{m})$. The length of $P$. cf. dolorosa (Louw et al., 2018) was considerably longer than $P$. bucculenta in the present study $(50-70 \mu \mathrm{m}$ compared to $19.2-30.8 \mu \mathrm{m})$. Cell length is, however, an unreliable morphometric character when identifying Pseudo-nitzschia species, as it depends on population age. The difference could reflect that Louw et al. (2018) looked at a field sample, while this study analysed cultured material. All other morphometric and morphological data match $P$. bucculenta. Thus $P$. cf. dolorosa in Louw et al. (2018) is considered to represent $P$. bucculenta, and therefore, the distribution of $P$. bucculenta also include northern regions of the nBUS.

A morphological comparison of $P$. bucculenta with the phylogenetically closely related $P$. dolorosa (Lundholm and Moestrup, 2006) shows similar, biseriate, striae, the two rows merging into one row of poroids in parts of the valve. Fibula and stria density overlap, but $P$. bucculenta has lower densities of fibulae (Welch's t-test, $\mathrm{p}<0.0001$ ) and stria (Welch's t-test, $\mathrm{p}<0.0001$ ). The density of poroids overlaps, although $P$. bucculenta has slightly fewer, however not significantly (Welch's t-test, $\mathrm{p}<0.05$ ). The girdle bands of $P$. dolorosa and $P$. bucculenta appear similar. The main difference between the two species is valve width. $P$. bucculenta is wider $(2.7-3.6 \mu \mathrm{m})$ than $P$. dolorosa (1.9-2.8 $\mu \mathrm{m}$ ) (Welch's t-test, $\mathrm{p}<0.0001$ ) (Figs. 4 and 8).

\subsection{Other Pseudo-nitzschia species off the coast of south-west Africa}

Molecular studies have previously reported presence of Pseudonitzschia in Angolan waters (Guannel et al., 2015), north of the ABF (Fig. 1). The species composition described was very different from that of the present study and at least five species were reported from Angola ( $P$. inflatula, $P$. galaxiae, $P$. cf. subpacifica and $P$. caciantha), that were not observed in

this study, suggesting different species compositions of the two areas. It seems likely that the south-west African waters harbour many different Pseudo-nitzschia species, possibly separated by upwelling and current systems, such as the LUC and the ABF.

\subsection{Domoic acid production in Namibian Pseudo-nitzschia species}

Namibian $P$. australis (one strain) and $P$. plurisecta (two strains) were found to produce DA (Table 6). Toxicity of $P$. australis has been reported globally and several studies have demonstrated toxicity in laboratory cultures (Trainer et al., 2012, Table 3$)$ ranging from low pDA $(0.026 \mathrm{pg}$ $\mathrm{DA} \mathrm{cell}^{-1}$ ) to high (37 pg DA cell ${ }^{-1}$ ), depending on laboratory conditions. The pDA contents found in the present study (Table 6) were relatively low compared to earlier findings (Trainer et al., 2012, Table 3), but match results by Baugh et al. (2006), where P. australis was tested for DA production during exponential growth and optimal conditions. The presence of $P$. australis in Namibian waters has previously been investigated by Louw et al. (2018), who found several blooms, including the previously mentioned bloom in 2004, where high pDA concentrations were measured and $P$. australis was the dominant species. This study confirms DA production in Namibian $P$. australis, verifying a likely coupling between high concentrations of $P$. australis and high pDA in the water and possibly the cause of the mortalities of marine wildlife in the area.

The observed toxicity in $P$. plurisecta (Table 6 ) is higher than in previous findings, e.g. Fernandes et al. (2014), where tDA was $0.0086-0.130 \mathrm{pg}$ cell $^{-1}$ during early stationary phase under optimal conditions, compared to tDA of $0.227-0.294 \mathrm{pg}^{-c^{-1}}$ in the present study. Since toxic $P$. plurisecta has now been found in Namibian waters, high densities of this species have the potential to influence Namibian marine food webs, including local fisheries and aquaculture.

Domoic acid production in $P$. fraudulenta was not found in the present study (Table 6). Toxicity in $P$. fraudulenta strains has previously been found by e.g. Fernandes et al. (2014) and Thessen et al. (2009), but the latter study also reported no detectable toxicity in other $P$. fraudulenta strains. $P$. fraudulenta has been present in high concentrations during several bloom events in Namibian waters (Louw et al., 2018). Although the present study did not reveal any DA production in $P$. fraudulenta, the toxicity reports from elsewhere indicate that high concentrations of this species can result in toxicity and therefore may have the potential to influence Namibian marine food webs.

Domoic acid production in Pseudo-nitzschia varies in laboratory experiments with both biotic and abiotic factors (reviewed by Trainer et al. (2012) and Lelong et al. (2012)). Recently it was found that the presence of copepods can induce toxin production in Pseudo-nitzschia species (e.g. Tammilehto et al., 2015; Harðardóttir et al., 2015). 
Keeping all of these various DA production triggers in mind, it is important to emphasize that it cannot be concluded that the strains found to be non-toxic will remain non-toxic under stress from one or more of these known DA production triggers. It has previously been shown that species believed to be non-toxic, did produce DA during other environmental conditions, as was the case in an earlier study by Harðardóttir et al. (2015), where P. obtusa suddenly produced DA triggered by the presence of copepods.

This study contributes to the knowledge gaps in Namibian research on toxic phytoplankton. Namibian and south-African waters are still relatively unstudied and more Pseudo-nitzschia species are believed to occur in these waters, as the species characterized in the present study do not account for all the diversity reported previously (Louw et al., 2018). Hence, continued efforts to examine the morphological, molecular phylogenetic, and toxigenic potential of this genus in the Benguela region are needed.

\section{Acknowledgements}

We thank the Namibian Ministry of Fisheries and Marine Resources for its support, as well as all colleagues involved in the data collection particularly the staff of the Environment Subdivision. We would like to thank the captain and crew on $R / V$ Mirabilis and $R / V$ !Anichab.

For technical assistance we wish to thank Lis Munk Frederiksen, Charlotte Hansen and Gert Hansen, Copenhagen. Funding for this project was by the Danish Research Council, Grant DFF-1323-00258, the Paul C. Silva Student Grant, student grants from Section of Evolutionary Genomics, NHMD, UCPH and the HelmholtzGemeinschaft Deutscher Forschungszentren through the research program "Polar regions And Coasts in the changing Earth System" (PACES) of the Alfred Wegener Institut-Helmholtz Zentrum für Polar- und Meeresforschung.[SS]

\section{Appendix A}

Table A1

Sampling stations from surveys with R/V Mirabilis and R/V !Anichab.

\begin{tabular}{|c|c|c|c|c|c|}
\hline Research vessel & Date & Transect & NM from shore & Location depth (m) & Station ID \\
\hline$R / V$ Mirabilis & $21 / 11 / 2016$ & $18^{\circ} \mathrm{S}$ & 2 & 45 & 18002 \\
\hline$R / V$ Mirabilis & $21 / 11 / 2016$ & $18^{\circ} \mathrm{S}$ & 10 & 132 & 18010 \\
\hline$R / V$ Mirabilis & $17 / 11 / 2016$ & $20^{\circ} \mathrm{S}$ & 70 & 438 & 20070 \\
\hline$R / V$ Mirabilis & $17 / 11 / 2016$ & $23^{\circ} \mathrm{S}$ & 40 & 153 & 23040 \\
\hline$R / V$ Mirabilis & $11 / 11 / 2016$ & $23^{\circ} \mathrm{S}$ & 50 & 240 & 23050 \\
\hline$R / V$ Mirabilis & $11 / 11 / 2016$ & $26^{\circ} \mathrm{S}$ & 20 & 181 & 26020 \\
\hline$R / V$ Mirabilis & $11 / 11 / 2016$ & $26^{\circ} \mathrm{S}$ & 30 & 199 & 26030 \\
\hline$R / V$ Mirabilis & $11 / 11 / 2016$ & $26^{\circ} \mathrm{S}$ & 50 & 309 & 26050 \\
\hline$R / V$ Mirabilis & $15 / 11 / 2016$ & $26^{\circ} \mathrm{S}$ & 70 & 507 & 26070 \\
\hline$R / V$ Mirabilis & $15 / 11 / 2016$ & $26^{\circ} \mathrm{S}$ & 90 & 1275 & 26090 \\
\hline$R / V ! A n i c h a b$ & $8 / 12 / 2016$ & $26^{\circ} 38^{\prime} \mathrm{S}$ & 20 & 190 & $20 \mathrm{NM}$ \\
\hline$R / V !$ Anichab & $8 / 12 / 2016$ & $26^{\circ} 38^{\prime} \mathrm{S}$ & 30 & 270 & $30 \mathrm{NM}$ \\
\hline$R / V !$ Anichab & $30 / 11 / 2016$ & $26^{\circ} 63^{\prime} \mathrm{S}$ & $<1$ & $\mathrm{n} / \mathrm{a}$ & Shearwater Bay A \\
\hline$R / V$ !Anichab & $1 / 12 / 2016$ & $26^{\circ} 63^{\prime} \mathrm{S}$ & $<1$ & $\mathrm{n} / \mathrm{a}$ & Shearwater Bay B \\
\hline
\end{tabular}

\section{Appendix B}

Table B1

Pseudo-nitzschia strains used in phylogenetic analyses including species, strain name, origin and accession number.

\begin{tabular}{|c|c|c|c|}
\hline Species & Strain designation & Origin & Accession number \\
\hline P. dolorosa & $300 \mathrm{C}$ & Ria de Aveiro, Portugal & DQ336153 \\
\hline P. dolorosa & BC_6_CL13_16 & French European Coast & KM245505 \\
\hline P. dolorosa & BP3 & Boca Piccola, Italy & DQ336151 \\
\hline P. dolorosa & AL-59 & The Gulf of Naples, Italy & DQ813835 \\
\hline P. dolorosa & AL-67 & The Gulf of Naples, Italy & DQ813837 \\
\hline P. dolorosa & AL-74 & The Gulf of Naples, Italy & DQ813838 \\
\hline P. dolorosa & Calif1 & Monterey Bay, California & DQ336152 \\
\hline P. dolorosa & Calif3 & Monterey Bay, California & DQ336154 \\
\hline P. simulans & MC281 & Daya Bay, South China Sea & MF374769 \\
\hline P. simulans & MC282 & Qingdao, the Yellow Sea, China & MF374770 \\
\hline P. simulans & MC940 & Wanshan Islands, East China Sea & MF374771 \\
\hline P. sabit & Ps103.1 & Colima, Mexico & KP288504 \\
\hline P. sabit & PNPD57 & Malacca Strait, Malaysia & KM400610 \\
\hline P. sabit & Ps103.2 & Colima, Mexico & KP288507 \\
\hline P. decipiens & Per1 & French Coast & EU523106 \\
\hline P. decipiens & GranCan4 & Arguineguin, Gran Canaria & DQ336157 \\
\hline P. decipiens & PnKk38 & Malacca Strait, Malaysia & KP337355 \\
\hline P. decipiens & Mex13 & Gulf of Mexico & DQ336156 \\
\hline$P$. galaxiae & Sydney4 & Bondi Beach, Sydney, Australia & DQ336158 \\
\hline P. galaxiae & Mex23 & Near Tuxpam, Mexico & AY257850 \\
\hline
\end{tabular}


Table B1 (continued)

\begin{tabular}{|c|c|c|c|}
\hline Species & Strain designation & Origin & Accession number \\
\hline P. subcurvata & $1-\mathrm{F}$ & Ross Sea & DQ329205 \\
\hline P. granii & PG & North East Pacific Ocean $\left(50^{\circ} \mathrm{N}, 145^{\circ} \mathrm{W}\right)$ & EU051654 \\
\hline P. micropora & B3 & Phong Bay, Vietnam & AY257847 \\
\hline$P$. arenysensis & MexA & Gulf of Mexico & DQ329211 \\
\hline P. arenysensis & Castell2 & Castellamare, Italy & DQ319212 \\
\hline P. arenysensis & BP1 & Boca Piccola, Italy & DQ336150 \\
\hline P. delicatissima & Tasm10 & Hobart, Tasmania, Australia & AY257848 \\
\hline P. delicatissima & Læsø2 & Læsø, Denmark & DQ329206 \\
\hline P. delicatissima & AL-22 & The Gulf of Naples, Italy & DQ813829 \\
\hline P. arctica & P2F2 & Disko Bay, West Greenland & KT589421 \\
\hline P. turgiduloides & $3-19$ & Ross Sea & AY257839 \\
\hline P. subfraudulenta & Pnmi82 & Sarawak, Malaysian Borneo & KR021301 \\
\hline P. fraudulenta & Lim1 & Limens, Spain & AY257840 \\
\hline P. fraudulenta & PNfra2 & Cabourg, English Channel & KY317920 \\
\hline P. fraudulenta & HY31H7 & South Korea & LC194948 \\
\hline P. fraudulenta & BC2_CL12_12 & French European coasts & KM245458 \\
\hline P. fraudulenta & $\mathrm{Pn}_{-} 8^{-}$ & Santa Cruz Wharf, California & КС329503 \\
\hline P. fraudulenta & Pn-12 & Chesapeake Bay & DQ445662 \\
\hline P. fraudulenta & F10 & French Coast & EU523102 \\
\hline P. fraudulenta & Ner-I2 & Bilbao estuary, Spain & KC409096 \\
\hline P. fraudulenta & Pi 2 & Aveiro coastal lagoon, Portugal & EU684232 \\
\hline
\end{tabular}

\begin{tabular}{|c|c|c|c|}
\hline Species & Strain designation & Origin & Accession number \\
\hline P. lineola & NW188 & Coastal WA, NE Pacific Ocean & JN050284 \\
\hline P. fryxelliana & NWFSC242 & Teawhit Head, WA, USA & JN050287 \\
\hline P. fryxelliana & NWFSC241 & Teawhit Head, WA, USA & JN050288 \\
\hline P. cuspidata & Tenerife8 & Tenerife, Canary Islands & AY257853 \\
\hline P. pseudodelicatissima & P11 & Portugal & AY257854 \\
\hline P. fukuyoi & Pnmi158 & Sarawak, Malaysian Borneo & KR021317 \\
\hline P. pseudodelicatissima & AL60 & The Gulf of Naples, Italy & DQ813836 \\
\hline P. cuspidata & Sydney1 & Bondi Beach, Sydney, Australia & AY257862 \\
\hline$P$. cuspidata & Mex12 & Near Tuxpam, Mexico & AY257852 \\
\hline P. plurisecta & Hobart5 & Hobart, Tasmania, Australia & AY257851 \\
\hline P. plurisecta & Ner-A1 & Bilbao estuary, Spain & KC409090. \\
\hline P. plurisecta & Ner-F1 & Bilbao estuary, Spain & КС409089 \\
\hline P. plurisecta & Ner-G4 & Bilbao estuary, Spain & KC409088 \\
\hline P. mannii & CIM_D-4 & Adriatic Sea & KX215915 \\
\hline P. caciantha & AL-56 & Unknown & DQ813834 \\
\hline P. subpacifica & RdA8 & Ria de Arousa, Spain & AY257860 \\
\hline P. calliantha & NL4 & The Sound, Denmark & JN050292 \\
\hline P. calliantha & C-AL-1 & The Gulf of Naples, Italy & DQ813842 \\
\hline P. hasleana & IEO-PS50 V & Mediterranean Sea & AM183801 \\
\hline P. hasleana & NW187 & Miramichi Bay (New Brunswick), Canada & JN085962 \\
\hline P. obtusa & $\mathrm{T} 5$ & Tromsø, Norway & DQ062667 \\
\hline P. seriata & Niss3 & Nissum Bredning, Denmark & AY257841 \\
\hline P. australis & delta 2 & Aveiro Lagoon, Portugal & EU684233 \\
\hline P. australis & $\emptyset \mathrm{M} 1$ & Aveiro, Portugal & AY257842 \\
\hline$P$. pungens var. pungens & V120(3)5 & North Sea, Belgium & AM778747 \\
\hline$P$. pungens var. pungens & Ner-J9 & Bilbao estuary, Spain & KC409100 \\
\hline$P$. pungens var. pungens & Ner-L1 & Bilbao estuary, Spain & KC409101 \\
\hline P. pungens var. averiensis & P24 & Costa Nova, Portugal & AY257845 \\
\hline$P$. pungens var. averiensis & Mex18 & Near Tuxpam, Mexico & AY257846 \\
\hline$P$. pungens var. averiensis & alfa3 & Aveiro coastal lagoon, Portugal & EU684235 \\
\hline$P$. pungens var. cingulata & US-115 & NE Pacific, USA & AM778804 \\
\hline$P$. pungens var. cingulata & US-123/a & NE Pacific, USA & AM778805 \\
\hline P. multiseries & mu3 & Monterey Bay, CA, USA & AY257844 \\
\hline P. brasiliana & $\mathrm{Xt} 3 \mathrm{C}$ & Van Phong Bay, Vietnam & DQ062662 \\
\hline P. brasiliana & Brasil8 & Sepetiba Bay, Brasil & unknown \\
\hline
\end{tabular}

\section{References}

Amato, A., Kooistra, W.H.C.F., Levialdi Ghiron, J.H., Mann, D.G., Pröshold, T., Montresor, M., 2007. Reproductive isolation among sympatric cryptic species in marine diatoms. Protist 158, 193-207.

Bakun, A., 1996. Patterns in the Ocean: Ocean Processes and Marine Population Dynamics. California Sea Grant College System. University of California Sea Grant California, USA, pp. 323 in cooperation with Centro de Investigaciones Biologicas de Noroeste, La Paz, Baja California Sur, Mexico.

Bates, S.S., Bird, C.J., Freitas, A.D., Foxall, R., Gilgan, M., Hanic, L.A., Johnson, G.R., McCulloch, A.W., Odense, P., Pocklington, R., Quilliam, M.A., Sim, P.G., Smith, J.C., Subba Rao, D.V., Todd, E.C.D., Walter, J.A., Wright, J.L.C., 1989. Pennate diatom
Nitzschia pungens as the primary source of domoic acid, a toxin in shellfish from eastern Prince Edward Island, Canada. Can. J. Fish. Aquat. Sci. 46, 1203-1215.

Bates, S.S., Hubbard, K.A., Lundholm, N., Montresor, M., Leaw, C.P., Pseudo-nitzschia, Nitzschia, and domoic acid: new research since 2011. Harmful Algae (in revision).

Baugh, K.A., Bush, J.M., Bill, B.D., Lefebvre, K.A., Trainer, V.L., 2006. Estimates of specific toxicity in several Pseudo-nitzschia species from the Washington coast, based on culture and field studies. Afr. J. Mar. Sci. 28, 403-407.

Blanco, J., Livramento, F., Rangel, I.M., 2010. Amnesic shellfish poisoning (ASP) toxins in plankton and molluscs from Luanda Bay, Angola. Toxicon 55, 541-546.

Busse, L.B., Venrick, E.L., Antrobus, R., Miller, P.E., Vigilant, V., Silver, M.W., Mengelt, C., Mydlarz, L., Prezelin, B.B., 2006. Domoic acid in phytoplankton and fish in San Diego CA. USA Harmful Algae 5, 91-101. 
Churro, C.I., Carreira, C.C., Rodrigues, F.J., Craveiro, S.C., Calado, A.J., Casteleyn, G., Lundholm, N., 2009. Diversity and abundance of potentially toxic Pseudo-nitzschia Peragallo in Aveiro coastal lagoon Portugal and description of a new variety, $P$. pungens var. aveirensis var. nov.. Diatom Res. 24, 35-62.

Fawcett, A., Pitcher, G.C., Bernard, S., Cembella, A.D., Kudela, R.M., 2007. Contrasting wind patterns and toxigenic phytoplankton in the southern Benguela upwelling system. Mar. Ecol. Prog. Ser. 348, 19-31.

Fernandes, L.F., Hubbard, K.A., Richlen, M.L., Smith, J., Bates, S.S., Ehrman, J., Léger, C., Mafra Jr., L.L., Kulis, D., Quilliam, M., Libera, K., McCauley, L., Anderson, D.M., 2014. Diversity and toxicity of the diatom Pseudo-nitzschia Peragallo in the Gulf of Maine, Northwestern Atlantic Ocean. Deep Sea Res. Part II 103, 139-162.

Florenchie, P., Lutjeharms, J.R., Reason, C.J.C., Masson, S., Rouault, M., 2003. The source of benguela Niños in the south Atlantic Ocean. Geophys. Res. Lett. 30, 1505-1508.

Fritz, L., Quilliam, M.A., Wright, J.L., Beale, A.M., Work, T.M., 1992. An outbreak of domoic acid poisoning attributed to the pennate diatom Pseudo-nitzschia australis. J. Phycol. 28, 439-442.

Guannel, M.L., Haring, D., Twiner, M.J., Wang, Z., Noble, A.E., Lee, P.A., Saito, M.A., Rocap, G., 2015. Toxigenicity and biogeography of the diatom Pseudo-nitzschia across distinct environmental regimes in the South Atlantic Ocean. Mar. Ecol. Prog. Ser. 526, 67-87.

Guillard, R.R.L., Hargraves, P.E., 1993. Stichochrysis immobilis is a diatom, not a chrysophyte. Phycologia 32, 234-236.

Hall, T.A., 1999. BioEdit: a user-friendly biological sequence alignment editor and analysis program for Windows 95/98/NT. Nucleic Acids Symp. Ser. 41, 95-98.

Hansen, A., Ohde, T., Wasmund, N., 2014. Succession of micro- and nanoplankton groups in ageing upwelled waters off Namibia. J. Mar. Syst. 140, 130-137.

Harðardóttir, S., Pančić, M., Tammilehto, A., Krock, B., Møller, E.F., Nielsen, T.G., Lundholm, N., 2015. Dangerous relations in the arctic marine food web: interactions between toxin producing Pseudo-nitzschia diatoms and Calanus copepodites. Mar. Drugs 13, 3809-3835.

Hart, T.J., Currie, R.I., 1960. The Benguela Current. University Press.

Hasle, G.R., 1993. Nomenclatural notes on marine planktonic diatoms. The family Bacillariaceae. In: Sims, P.A. (Ed.), Progress in diatom studies, Contributions to taxonomy, ecology and nomenclature. Special volume in honour of Robert Ross on the occasion of his 80th Birthday. Beihefte zur Nova Hedwigia 106, 315-321.

Hasle, G.R., Lange, C.B., Syvertsen, E.E., 1996. A review of Pseudo-nitzschia, with special reference to the Skagerrak, North Atlantic, and adjacent waters. Helgoländer Meeresuntersuchungen 50, 131-175.

Hasle, G.R., 1965. Nitzschia and Fragilariopsiss pecies studied in the light and electron microscopes: II. The group Pseudonitzschia. Skr. Norske Vidensk-Akad. I. Mat.-Nat. Kl. Ny Serie 18, 1-45.

Hasle, G.R., 2002. Are most of the domoic acid-producing species of the diatom genus Pseudo-nitzschia cosmopolites? Harmful Algae 1, 137-146.

Hubbart, B., Pitcher, G.C., Krock, B., Cembella, A.D., 2012. Toxigenic phytoplankton and concomitant toxicity in the mussel Choromytilus meridionalis off the west coast of South Africa. Harmful Algae 20, 30-41.

Hutchings, L., Van der Lingen, C.D., Shannon, L.J., Crawford, R.J.M., Verheye, H.M.S., Bartholomae, C.H., van der Plas, A.K., Louw, D.C., Kreiner, A., Ostrowski, M., Fidel, Q., Barlow, R.G., Lamont, T., Coetzee, J., Shillington, F., Veitch, J., Currie, J.C., Monteiro, P.M.S., 2009. The Benguela current: an ecosystem of four components. Prog. Oceanogr. 83, 15-32.

Krock, B., Tillmann, U., John, U., Cembella, A.D., 2008. LC-MS-MS aboard ship: tandem mass spectrometry in the search for phycotoxins and novel toxigenic plankton from the North Sea. Anal. Bioanal. Chem. 392, 797-803.

Lachkar, Z., Gruber, N., 2012. A comparative study of biological production in eastern boundary upwelling systems using an artificial neural network. Biogeosciences 9, 293-308.

Lefebvre, K.A., Quakenbush, L., Frame, E., Huntington, K.B., Sheffield, G., Stimmelmayr, R., Bryan, A., Kendrick, P., Ziel, H., Goldstein, T., Snyder, J.A., Gelatt, T., Gulland, F., Dickerson, B., Gill, V., 2016. Prevalence of algal toxins in Alaskan marine mammals foraging in a changing arctic and subarctic environment. Harmful Algae 55, 13-24.

Lelong, A., Hégaret, H., Soudant, P., Bates, S.S., 2012. Pseudo-nitzschia (Bacillariophyceae) species, domoic acid and amnesic shellfish poisoning: revisiting previous paradigms. Phycologia 51, 168-216.

Li, Y., Huang, C.X., Xu, G.S., Lundholm, N., Teng, S.T., Wu, H., Tan, Z., 2017. Pseudonitzschia simulans sp. nov. (Bacillariophyceae), the first domoic acid producer from Chinese waters. Harmful Algae 67, 119-130.

Lim, H.C., Lim, P.T., Teng, S.T., Bates, S.S., Leaw, C.P., 2014. Genetic structure of Pseudonitzschia pungens (Bacillariophyceae) populations: implications of a global diversification of the diatom. Harmful Algae 37, 142-152.

Louw, D.C., van der Plas, A.K., Mohrholz, V., Wasmund, N., Junker, T., Eggert, A., 2016. Seasonal and interannual phytoplankton dynamics and forcing mechanisms in the Northern Benguela upwelling system. J. Mar. Syst. 157, 124-134.

Louw, D.C., Doucette, G.J., Voges, E., 2017. Annual patterns, distribution and long-term trends of Pseudo-nitzschia species in the northern Benguela upwelling system. J. Plankton Res. 39, 35-47.

Louw, D.C., Doucette, G.J., Lundholm, N., 2018. Morphology and toxicity of Pseudonitzschia species in the northern Benguela Upwelling System. Harmful Algae 75, $118-128$.

Lundholm, N., Daugbjerg, N., Moestrup, Ø., 2002. Phylogeny of the Bacillariaceae with emphasis on the genus Pseudo-nitzschia (Bacillariophyceae) based on partial LSU
rDNA. Eur. J. Phycol. 37, 115-134.

Lundholm, N., Moestrup, Ø., Kotaki, Y., Hoef-Emden, K., Scholin, C., Miller, P., 2006. Inter-and intraspecific variation of the Pseudo-nitzschia delicatissima complex (Bacillariophyceae) illustrated by rRNA probes, morphological data and phylogenetic analyses. J. Phycol. 42, 464-481.

Lundholm, N., Bates, S.S., Baugh, K.A., Bill, B.D., Connell, L.B., Léger, C., Trainer, V.L., 2012. Cryptic and pseudo-cryptic diversity in diatoms-with descriptions of Pseudonitzschia hasleana sp. nov. and P. fryxelliana sp. nov. J. Phycol. 48, 436-454.

Lundholm, N., 2018. Bacillariophyceae, in IOC-UNESCO Taxonomic Reference List of Harmful Micro Algae. Available online at http://www.marinespecies.org/hab. Accessed on 2018 May 05.

Mai, J.C., Coleman, A.W., 1997. The internal transcribed spacer 2 exhibits a common secondary structure in green algae and flowering plants. J. Mol. Evol. 44, 258-271.

Malviya, S., Scalco, E., Audic, S., Vincent, F., Veluchamy, A., Poulain, J., Wincker, P., Iudicone, D., de Vargas, C., Bittner, L., Zingone, A., Bowler, C., 2016. Insights into global diatom distribution and diversity in the world's ocean. Proc. Natl. Acad. Sci. 113, 1516-1525.

Marangoni, C., Pienaar, R.N., Sym, S.D., Pitcher, G.C., 2001. Pseudo-nitzschia australis Frenguelli from Lambert's Bay, South Africa. Proc. Microsc. Soc. S. Afr. 31, 53.

McCabe, R.M., Hickey, B.M., Kudela, R.M., Lefebvre, K.A., Adams, N.G., Bill, B.D., Gulland, F.M.D., Thomson, R.E., Cochlan, W.P., Trainer, V.L., 2016. An unprecedented coastwide toxic algal bloom linked to anomalous ocean conditions. Geophys. Res. Lett. 43, 366-376.

Meeuwis, J.M., Lutjeharms, J.R.E., 1990. Surface thermal characteristics of the AngolaBenguela front. S. Afr. J. Mar. Sci. 9, 261-279.

Mohrholz, V., Bartholomae, C.H., van der Plas, A.K., Lass, H.U., 2008. The seasonal variability of the northern Benguela undercurrent and its relation to the oxygen budget on the shelf. Cont. Shelf Res. 28, 424-441.

Nash, S.B., Baddock, M.C., Takahashi, E., Dawson, A., Cropp, R., 2017. Domoic acid poisoning as a possible cause of seasonal cetacean mass stranding events in Tasmania. Aust. Bull. Environ. Contam. Toxicol. 98, 8-13.

Orive, E., Pérez, Aicua, L., David, H., García-Etxebarria, K., Laza-Martínez, A., Seoane, S., Miguel, I., 2013. The genus Pseudo-nitzschia (Bacillariophyceae) in a temperate estuary with description of two new species: Pseudo-nitzschia plurisecta sp. nov. and Pseudo-nitzschia abrensis sp. nov. J. Phycol. 49, 1192-1206.

Posada, D., Crandall, K.A., 1998. Modeltest: testing the model of DNA substitution. Bioinformatics 14, 817-818.

Rae, C.D., 2005. A demonstration of the hydrographic partition of the Benguela upwelling ecosystem at 26 40'S. Afr. J. Mar. Sci. 27, 617-628.

Ronquist, F., Huelsenbeck, J.P., 2003. MrBayes 3: Bayesian phylogenetic inference under mixed models. Bioinformatics 19, 1572-1574.

Rouault, M., Illig, S., Lübbecke, J., Koungue, R.A.I., 2017. Origin, development and demise of the 2010-2011 Benguela Niño. J. Mar. Syst. http://dx.doi.org/10.1016/j. jmarsys.2017.07.007. in press, Available online 29 July 2017.

Seeyave, S., Probyn, T.A., Pitcher, G.C., Lucas, M.I., Purdie, D.A., 2009. Nitrogen nutrition in assemblages dominated by Pseudo-nitzschia spp., Alexandrium catenella and Dinophysis acuminata off the west coast of South Africa. Mar. Ecol. Prog. Ser. 379, 91-107.

Shannon, L.V., Boyd, A.J., Brundrit, G.B., Taunton-Clark, J., 1986. On the existence of an El Niño-type phenomenon in the Benguela system. J. Mar. Res. 44, 495-520.

Shannon, L.V., Agenbag, J.J., Buys, M.E.L., 1987. Large-and mesoscale features of the Angola-Benguela front. South African Journal of Marine Science 5, 11-34.

Swofford, D.L., 2002. PAUP*. Phylogenetic Analysis Using Parsimony (*and Other Methods) 4.0 Beta for Linux/UNIX. Sinauer Associates.

Tammilehto, A., Nielsen, T.G., Krock, B., Møller, E.F., Lundholm, N., 2015. Induction of domoic acid production in the toxic diatom Pseudo-nitzschia seriata by calanoid copepods. Aquat. Toxicol. 159, 52-61.

Teitelbaum, J., Carpenter, S., Cashman, N.R., 1990. Neurologic sequelae after ingestion of mussels contaminated with domoic acid. N. Engl. J. Med. 323, 1632-1633.

Teng, S.T., Lim, H.C., Lim, P.T., Rivera-Vilarelle, M., Quijano-Scheggia, S., Takata, Y., Quilliam, M.A., Wolf, M., Bates, S.S., Leaw, C.P., 2015. A non-toxigenic but morphologically and phylogenetically distinct new species of Pseudo-nitzschia, Pseudonitzschia sabit sp. nov. (Bacillariophyceae). J. Phycol. 51, 706-725.

Thessen, A.E., Bowers, H.A., Stoecker, D.K., 2009. Intra-and interspecies differences in growth and toxicity of Pseudo-nitzschia while using different nitrogen sources. Harmful Algae 8, 792-810.

Thompson, J.D., Higgins, D.G., Gibson, T.J., 1994. CLUSTAL W: improving the sensitivity of progressive multiple sequence alignment through sequence weighting, positionspecific gap penalties and weight matrix choice. Nucleic Acids Res. 22, 4673-4680.

Trainer, V.L., Bates, S.S., Lundholm, N., Thessen, A.E., Cochlan, W.P., Adams, N.G., Trick, C.G., 2012. Pseudo-nitzschia physiological ecology, phylogeny, toxicity, monitoring and impacts on ecosystem health. Harmful Algae 14, 271-300.

Villac, M.C., Fryxell, G.A., 1998. Pseudo-nitzschia pungens var. cingulata var. nov. (Bacillariophyceae) based on field and culture observations. Phycologia 37, 269-274.

Wang, P., Liang, J., Lin, X., Chen, C., Huang, Y., Gao, Y., Gao, Y., 2012. Morphology, phylogeny and ITS-2 secondary structure of Pseudo-nitzschia brasilian (Bacillariophyceae), including Chinese strains. Phycologia 51, 1-10.

White, T.J., Bruns, T., Lee, S.J.W.T., Taylor, J.W., 1990. Amplification and direct sequencing of fungal ribosomal RNA genes for phylogenetics. PCR Protoc. 18, 315-322.

Zuker, M., 2003. Mfold web server for nucleic acid folding and hybridization prediction. Nucleic Acids Res. 31, 3406-3415. 